\title{
Valuation for the purposes of a wealth tax
}

\author{
Stephen Daly $^{1}$ ｜ Helen Hughson ${ }^{2} \quad$ Glen Loutzenhiser ${ }^{3}$
}

${ }^{1}$ King's College London

${ }^{2}$ London School of Economics

${ }^{3}$ University of Oxford

\section{Correspondence}

Stephen Daly, Dickson Poon School of Law, King's College London, Strand, London WC2R 2LS, UK. Email: stephen.daly@kcl.ac.uk

\begin{abstract}
This paper considers the scale and prevalence of valuation issues under a wealth tax. Valuation issues are frequently cited in the literature as the most difficult aspect of wealth taxes. We examine some of the most problematic asset types from a valuation perspective. We also consider a range of solutions to manage these concerns, drawing on international experience and the approaches already taken for other taxes within the UK system. We conclude that satisfactory options for arriving at a value for wealth tax purposes are available even for the most problematic assets. We also estimate that the absolute number of taxpayers likely to pay substantial valuation fees is small, and that, in aggregate, valuation costs could be contained to around 0.1 per cent or less of total chargeable assets, even if they are substantial for some individual taxpayers.
\end{abstract}

\section{K E Y W O R D S}

net wealth tax, tax policy, valuation, open market value, banding, pension assets, business assets, agricultural property, residential property, artwork

\section{JEL CLASS I F I C A T I O N}

E21

\section{1 | INTRODUCTION}

This paper considers valuation issues under a net wealth tax and develops rough estimates of the costs taxpayers may face in establishing a precise estimate of their total wealth. Valuation issues are frequently cited in the literature as the most problematic aspect of wealth taxes. Sandford, Willis and Ironside (1975, pp. 159-79) devote an entire chapter to valuation issues under a wealth tax. The Mirrlees Review ${ }^{1}$ and Thuryoni (2003, p. 329) both highlight the problem of unevenness of application of wealth taxes and valuation difficulties. In their chapter on capital and wealth taxes, Evans et al.

\footnotetext{
${ }^{1}$ Mirrlees et al., 2011, p. 347.
}

This is an open access article under the terms of the Creative Commons Attribution License, which permits use, distribution and reproduction in any medium, provided the original work is properly cited.

(C) 2021 The Authors. Fiscal Studies published by John Wiley \& Sons Ltd. on behalf of Institute for Fiscal Studies 
(2017, p. 104) emphasise the problems of valuation as well as disclosure. The Meade Committee, ${ }^{2}$ Peacock (1963, pp. 398-99) and Atkinson (1972, p. 158) all consider the administrative problems with wealth taxes, focusing not only on valuation but also on assessment and evasion. Valuation issues are examined in some detail by OECD (2018, pp. 85-87), which also provides helpful examples of current and historical valuation practices.

This paper begins by outlining some general issues for valuation under a wealth tax, including our choice of 'open market value' as the preferred valuation method and when it might be appropriate to deviate from that method. Next, we consider the most problematic asset types from a valuation perspective and examine a range of solutions to manage these concerns. The paper concludes with some empirical estimates of costs of valuation. Clearly, the overall design of the wealth tax will affect the magnitude of the valuation issues and costs - in particular, decisions on the base. Valuation issues are a much greater concern under a broad-based annual wealth tax than under a narrowly based tax with a high threshold along with specific exemptions for problematic assets, or under a one-off wealth tax as discussed by Advani, Chamberlain and Summers (2020) in the Final Report of the Wealth Tax Commission (hereafter referred to as ACS), though relative valuation costs may be higher when a high threshold is used. At the same time, however, it should be borne in mind that technological change can make contemporaneous valuation easier and cheaper by providing larger and more accessible databases on market transactions, as exemplified by property websites, such as Rightmove and Zoopla, and specialist Internet auction sites.

This paper includes examples of how valuation concerns have been addressed in current and past wealth taxes, drawing on a number of the Wealth Tax Commission's Working Papers (listed in the References section) and other sources including the IBFD Country Tax Guides. ${ }^{3}$ We also refer to experience with related taxes such as the UK's inheritance tax (IHT), capital gains tax (CGT) and annual tax on enveloped dwellings (ATED), which we use to develop estimates of valuation costs to taxpayers in the final section of this paper. It should be noted that, in general, valuation is more of a concern under an annual wealth tax than under inheritance/estate taxes because relatively few estates pay IHT and a deceased's property often needs to be properly valued and possibly sold anyway, for example, where the property (or its value) is to be distributed amongst multiple beneficiaries. ${ }^{4}$ IHT is also generally a one-time valuation only, which means not only that administrative costs are incurred less often but also that there is more at stake on each valuation. These considerations would also be relevant to a one-off wealth tax, as discussed in ACS. Except during those points where the paper specifically indicates otherwise, however, the comments and analysis here are applicable equally to both an annual wealth tax and a one-off wealth tax.

The paper proceeds as follows. In Section 2, we argue that open market value should generally be used to determine the value of assets. However, deviations may be necessary and, to that end, determining whether to do so should be guided by the principles of certainty, feasibility, consistency and integrity. We note also the potential use of banding for policymakers, highlighting its advantages and disadvantages. In Section 3, we find that open market valuation can work well in respect of some assets, such as defined contribution pensions, residential and commercial property, listed shares and shares in large private companies, agricultural land, and works of art. Shares in smaller private companies, defined benefit pensions, antiques and other heritage items present greater difficulties. For these, a differentiated approach to valuation may need to be taken, such as excluding human capital for the purposes of valuing smaller private companies (a departure from open market value). The paper considers other departures from open market valuation, such as using a formula to value small businesses or using insurance values for antiques and other valuables, though it tentatively concludes that neither should be adopted. In Section 4, we examine the number of taxpayers likely to be grappling

\footnotetext{
${ }^{2}$ Meade, 1978, pp. 354-58.

${ }^{3}$ See IBFD Country Tax Guides, Individual Taxation, Taxes on Capital, Net Wealth Tax, on the IBFD Tax Research Platform at https://www.ibfd.org/IBFD-Tax-Portal/About-Tax-Research-Platform.

${ }^{4}$ See OECD (2018, p. 64) and citing Boadway, Chamberlain and Emmerson (2010).
} 
with valuation issues, and how much of a financial imposition the need to precisely measure their wealth would be.

\section{2 | OPEN MARKET VALUE UNDER A WEALTH TAX}

\subsection{Introduction}

Valuation under a wealth tax ought to aim to reflect 'the price which an asset would fetch as between a willing buyer and willing seller in a market open to all comers', ${ }_{5}^{5}$ referred to as the open market value. Open market valuation provides an objective means of determining the store of a person's wealth and their position relative to others by focusing on consumption that someone could finance if they chose to sell the assets. As Sandford et al. (1975, p. 159) rightly note, a wealth tax is a tax on resources and 'market value is the natural measure of those resources'. The consensus in the literature, which is also reflected in current and historical international practice, is that the basis for valuing assets for the purposes of a wealth tax should be open market value. ${ }^{6}$ OECD $(2018$, p. 85) also takes the position that '[a]ssets should ideally be assessed at their market value, defined as the price at which an asset would be traded in a competitive market'. Saez and Zucman (2019a, p. 32) similarly state: '[t]he general principle guiding valuations should be that all assets should be assessed at their prevailing market value'.

There are, it should be noted, other possible valuation methodologies that depart from open market valuation. ${ }^{7}$ One, for instance, is subjective valuation. This would focus on the importance of assets to the owner and whether, for instance, they provide the owner with joy, pleasure and security. This might fit with a broad philosophical definition of wealth, though this is not one that is adopted here. Further, it would collapse as a viable approach once administration problems, which render it impractical, are considered (for instance, it is difficult to see how taxpayers lying about subjective values could be feasibly regulated).

Another is formulaic valuation; in other words, valuation by recourse to a formula. For instance, some countries use 'book values' as a basis for determining the value of a business, as will be explained. It might be argued that formulae can provide a crude approximation of open market value, but we believe that formulaic valuation is instead better understood simply as distinct from open market valuation. Critically, formulae are not pegged to the assumptions that underpin open market valuation (discussed below). Formulae certainly can have a place in determining values for the purposes of a wealth tax however, as will be explored in Section 2.4, where using open market value is impractical.

Proceeding on the basis that open market value is the preferred valuation basis, there are essentially three approaches that can be taken to determine this. In their simplest terms, these are based on (1) market transactions, (2) future income and (3) cost of replacement. These reflect the economic principles of price equilibrium, anticipation of benefits, and substitution, respectively. ${ }^{8}$ One can value an asset by way of comparison with an identical or comparable asset for which price information is available (market transactions), by converting future cash flow to a single currency (income), or by calculating the cost to obtain an asset of equal utility, whether by purchase or by construction (cost). ${ }^{9}$ Each reflects different practical constraints. A market transactions approach should be adopted for instance where: '(a) the subject asset has recently been sold in a transaction appropriate for

\footnotetext{
${ }^{5}$ Sandford et al., 1975, p. 159.

${ }^{6}$ See, for example, Sandford et al. (1975, p. 159).

${ }^{7}$ Repetti, 2000, p. 609.

${ }^{8}$ International Valuation Standards Council (IVSC), 2019, para 10.1.

${ }^{9}$ See IVSC (2019, paras 20.1, 40.1, 60.1).
} 
consideration under the basis of value, (b) the subject asset or substantially similar assets are actively publicly traded, and/or (c) there are frequent and/or recent observable transactions in substantially similar assets'. ${ }^{10}$ This would be the case with residential property for owner occupation (see Section 3.2). Meanwhile, the income approach should be adopted where '(a) the income-producing ability of the asset is the critical element affecting value from a participant perspective, and/or (b) reasonable projections of the amount and timing of future income are available for the subject asset, but there are few, if any, relevant market comparables'. ${ }^{11}$ This would be the case with commercial property investment (see Section 3.2).

\section{2 | Existing uses of open market value}

In adopting open market value as the preferred basis of valuation for a wealth tax, we note that this position is consistent with a number of existing UK taxes, including council tax, IHT, CGT and ATED. ${ }^{12}$ For IHT and CGT purposes, the general rule is 'the value at any time of any property shall for the purposes of this Act be the price which the property might reasonably be expected to fetch if sold in the open market at that time'. ${ }^{13}$ This general statutory rule is subject to the following further clarification: "that price shall not be assumed to be reduced on the ground that the whole property is to be placed on the market at one and the same time'. ${ }^{14}$ In other words, arguments about flooding the market by the sale are not taken into account. For CGT purposes, in the majority of cases, the market value simply will be the consideration agreed between the buyer and seller. However, a market value determination is required for disposals/acquisitions made otherwise by way of a bargain made at arm's length, for example, a gift to a family member or a settlement into trust. ${ }^{15}$ Capital assets are also revalued for CGT purposes to market value on death. ${ }^{16}$

The tax legislation provides further assumptions in respect of the information that is available to the hypothetical buyer. Section 168 of IHTA 1984 provides that the buyer would have available 'all the information which a prudent prospective purchaser might reasonably require if he were proposing to purchase them from a willing vendor by private treaty and at arm's length'. Section 273(3) provides similarly that in respect of the valuation of shares, 'there is available to any prospective purchaser of the asset in question all the information which a prudent prospective purchaser of the asset might reasonably require if he were proposing to purchase it from a willing vendor by private treaty and at arm's length'. The legislation in turn is supplemented by a number of assumptions that have developed through the case law, such as that for the purposes of the hypothetical sale, the vendor would divide the property to be valued into whatever natural lots would achieve the best overall price; that all preliminary arrangements necessary for the sale to take place have been carried out prior to the valuation date; and the property is offered for sale on the open market by whichever method of sale will achieve the best price. ${ }^{17}$

Open market valuation, however, can be manipulated - and, to this end, the tax legislation provides anti-avoidance rules. In situations where bundles of assets are held jointly, for instance, it may be the case that as a bunch the assets are worth more than the cumulative sum of the individual components. Thus, in the case of a family business, the market value of the total assets in the business may be worth

\footnotetext{
${ }^{10}$ IVSC, 2019, para 20.2.

${ }^{11}$ IVSC, 2019, para 40.2.

${ }^{12}$ Mackie, 2020; Pentelow, 2020; Tennant, 2020.

${ }^{13}$ Inheritance Tax Act (IHTA) 1984, s.160; see also Taxation of Chargeable Gains Act (TGCA) 1992, s.272.

${ }^{14}$ IHTA 1984, s.160; TCGA 1992, s.272(2).

15 TCGA 1992, s.17.

${ }^{16}$ TCGA 1992, s.62.

${ }^{17}$ See Pentelow (2020) and Tennant (2020); see further Mackie (2020).
} 
less than the whole business together. In order to prevent individuals from fragmenting ownership so as to reduce the tax base, it has been necessary to introduce anti-fragmentation provisions, such as in respect of the 'related property' rules for IHT purposes. ${ }^{18}$ Anti-fragmentation rules are also necessary where high exemption thresholds are used for individuals in order to prevent shifts in ownership between family members. ${ }^{19}$

Finally, open market value is used as the main (though not the only) valuation approach for many non-tax purposes as well. One example is the law covering the compulsory acquisition of land. ${ }^{20}$ Another is the IVSC, which uses 'market value', equivalent to open market value, as one of six bases of value. There 'market value' is defined as 'the estimated amount for which an asset or liability should exchange on the valuation date between a willing buyer and a willing seller in an arm's length transaction, after proper marketing and where the parties had each acted knowledgeably, prudently and without compulsion'. ${ }^{21}$ Another equivalent to open market value, namely 'fair value', is adopted in International Financial Reporting Standard (IFRS) $13 .{ }^{22}$ IFRS 13 kicks in where another IFRS designates that fair value ought to be used, for instance with IFRS 2 in the case of share-based payment transactions. There, 'fair value' is defined as 'the price that would be received to sell an asset or paid to transfer a liability in an orderly transaction between market participants at the measurement date'. When seeking to draw upon the methods of valuation that are adopted for non-tax purposes however, caution is necessary as these may not strive to truly reflect the value of assets on the open market. Take the valuation of assets on divorce for instance. ${ }^{23}$ Here, parties may wish to acquire certain assets for sentimental purposes and the value that they are willing to place upon them would be higher than they would be able to fetch on the open market. Or conversely, parties in a divorce may accept a lower value for certain assets in order to finalise proceedings.

\subsection{Challenges in determining open market value}

The fact that determinations of open market value may rely heavily upon assumptions begins to give an indication of the inevitable issues that arise. Thus, where there is no active market, few transactions and/or where parties are not at arm's length, open market value will be difficult to determine. In such cases, each of the open market valuation approaches (market transactions, income, cost) will encounter difficulties, even where professional judgement would indicate that one approach over another is considered appropriate (see, for instance, Section 3.3), thereby giving rise to conflicting calculations.

To that end, although Sandford et al. (1975, p. 159) conclude that market value 'may be the best measure we have of resources', they also discuss some of its 'many defects'. These include the fact that market value can be influenced by the form in which assets are held (e.g. quoted versus unquoted companies otherwise similar in size and profitability). Focusing just on market value issues with quoted shares, Sandford et al. (1975) cite disproportionate movements in share prices from relatively small quantity sales; differences in prices for buyers and sellers and minority versus large block holders of shares; price fluctuations based on unfounded and malicious rumours; and share prices that exceed or are exceeded by the underlying tangible assets. More broadly, differences in the degree of willingness of either sellers or buyers can lead to price variance one day to the next, especially on unique assets including houses, shares in private companies, art and jewellery. ${ }^{24}$ Sandford et al. (1975,

\footnotetext{
${ }^{18}$ IHTA 1984, s.161; Pentelow, 2020.

${ }^{19}$ Chamberlain, 2021.

${ }^{20}$ Clark and $\mathrm{Fu}, 2020$.

${ }^{21}$ International Valuation Standards Council, 2016, p. 8; Mackie, 2020.

${ }^{22}$ Mackie, 2020.

${ }^{23}$ Nelder, 2020.

${ }^{24}$ Sandford et al., 1975, pp. 159-60.
} 
p. 161) argue that these differences lead to ranges in value that must be recognised and, further, that the wealth tax should aim to use the bottom of the range for inherited or gifted assets and a maximum amount half way between the top and bottom amounts for purchased assets.

OECD (2018, p. 85) takes a similar approach, stating that 'the biggest practical difficulties with net wealth taxes is determining the value of infrequently traded assets', and concludes that market values should be used but 'possibly at a slightly discounted rate'. For example, the OECD suggested that 'the tax base could be limited to a fixed percentage of that market value (e.g. 80-85 per cent) to prevent valuation disputes but also to take into account certain costs that may be incurred to hold or maintain the assets'. ${ }^{25}$ Of course, this is not actually a solution to valuation as a value still needs to be determined in order to assess a discounted percentage of it. The OECD recommended comparable valuation approaches across asset classes to avoid distortion between assets but suggested insured values could be used instead of market values for assets such as artwork and high-value jewellery that are infrequently traded and therefore hard to value. ${ }^{26}$ The Labour Chancellor Denis Healey's 1974 Green Paper adopted open market value on the day on which the property is to be valued as the general valuation approach for its proposed wealth tax, but with supplementary rules for particular types of assets. ${ }^{27}$ The Meade Committee took a similar approach, describing an open market valuation for an annual wealth tax as theoretically preferable, but then commented favourably on the use of standardisation methods for certain problematic asset types including pension rights, valuable personal chattels, business assets, and real property on the grounds of reduced administrative and compliance costs, and reduced uncertainty. The Committee stated '[i]t is proper that these considerations should on occasion take precedence over the desire to obtain a genuine open market valuation' ${ }^{28}$

Finally, although open market value has been the primary basis for valuation adopted by other countries for their wealth taxes, ${ }^{29}$ many countries then depart from this ideal to some degree by providing preferential valuation rules or discounts from open market value for particular types of assets including primary residences, business assets and agricultural property. ${ }^{30}$

\subsection{Deviations from open market value}

Whilst we adopt open market value as the preferred primary basis of valuation for a wealth tax, we also recognise that other considerations may justify deviating from it, particularly with certain problematic asset types, as discussed further below. Accepting that nothing which deviates from the general approach will provide an unimpeachable option, it is prudent to briefly set out criteria by which to judge both the application of different approaches to open market valuation for particular assets and also deviations from open market value. The goal should be to assess whether deviations better fit the (non-mutually exclusive) criteria set out below than open market valuation.

It is also important to recognise that the discussion of valuation does not arise in a vacuum independent of political or other concerns around the structuring of a wealth tax. Thus, deviations from open market valuation might be deemed more or less desirable when combined with other design features. For instance, under a banded system of charges (discussed below), valuation issues would be alleviated near the middle of a band (where small differences in valuation would not affect the charge at all) but would be exacerbated near the thresholds (where small differences in valuation could result in a discrete change in the level of charge). If there are large nil rate bands, then this might alleviate

\footnotetext{
${ }^{25}$ OECD, 2018, p. 86.

${ }^{26}$ OECD, 2018, p. 86.

${ }^{27}$ HMSO, 1974, p. 14.

${ }^{28}$ Meade, 1978 , p. 355

${ }^{29}$ Sandford et al., 1975, p. 159.

${ }^{30}$ See OECD (2018, p. 85) and the discussion in Section 3.
} 
valuation issues for a large chunk of society, but it would create 'wealth splitting' issues, as are seen in the case of 'income splitting' amongst family members. Whilst conscious of these issues and the need accordingly to be flexible, we proceed to discuss valuation in its purest form in order to give a neutral surface on which these and other stones can be added to form a rich mosaic. It is only by knowing the starting plane that the consequence of any deviation can be understood.

ACS reject adopting departures from the open market value 'because any simpler approach is liable to lead to unfairness in individual cases'. ${ }^{31}$ They are 'liable to generate distortions by asset type and opportunities for avoidance' and 'there is evidence that they produce horizontal inequity that results in resentment and undermines public support'. ${ }^{32}$ To ensure that no deviation would be needed in the case of an annual wealth tax, ACS consider that two conditions would need to be satisfied in respect of design: (1) that a 'threshold that is high enough to reduce the volume of taxpayers to the point where the number of valuations required each year is manageable from the perspective of both HMRC and the capacity of professional valuers'; (2) that 'a rate that is high enough that the tax collected from each taxpayer is a sufficient multiple of the (mostly fixed) costs of valuation to make these costs worthwhile'. ${ }^{33}$ Policymakers considering the introduction of an annual wealth tax without satisfying these conditions would, however, need to countenance departures from open market value and, to that end, a discussion here of the relevant criteria is merited.

The (non-mutually exclusive) criteria of certainty, feasibility, consistency and integrity, as elaborated upon below, should be used to judge the merit of using alternative approaches to open market valuation or deviations from open market valuation. These criteria are deduced from the fact that a tax on wealth would be imposed through law and the condition underpinning that law of an objective means of determining the store of a person's wealth and their position relative to others. Though we believe that each of these criteria is worthy of consideration in its own right, they rank in importance in the order that they are laid out below. Certainty ought to be accorded greatest relative weight on account of the fact that the wealth tax itself will be imposed by law. Laws should provide certainty, whatever their rationales. Feasibility is thereafter, as it bears so heavily upon the possibility that an objective measure of wealth across taxpayers can be obtained. Integrity should rank last given that issues around planning and disputes will be inevitable no matter the valuation rules adopted, thereby leaving consistency in third place.

\subsection{1 | Certainty}

The rule of law, in its thinnest conception, requires that people ought to be aware of their tax liabilities. ${ }^{34}$ Whilst absolute certainty is unattainable, and therefore not a requirement of the rule of law, there ought to be a sufficient degree of precision in order that people can plan their lives. A tax on wealth would be imposed through law, as would the specifications for valuation, and therefore the valuation of assets under that law should be capable of informing individuals of their liabilities with a sufficient degree of precision: the rules for calculating liability ought to be clear (and not arbitrary), stable (and not changed with retroactive effect) and accessible (and not difficult to unearth).

\subsection{2 | Feasibility}

It is desirable that the method of valuation should not be overly resource intensive, as that would be to strip away the resources from which the revenue should be raised (either directly or indirectly) and

\footnotetext{
${ }^{31}$ Advani et al., 2020, p. 57.

32 Advani et al., 2020, p. 98.

${ }^{33}$ Advani et al., 2020, p. 99.

${ }^{34}$ Daly, 2020, Chapter 3.
} 
would have consequent effects on people's positions relative to each other. Here, we consider four factors that underpin feasibility.

(1) Administrative and compliance costs, from both the tax authority and the taxpayer perspective. Sandford et al. (1975, p. 161) argued that the choice of valuation methods in practice must be influenced by the need to keep down administrative and compliance costs, and reduce as much as possible uncertainty about, and delay in arriving at, valuations. The Meade Committee echoed these considerations in recognising that standard valuation approaches for problematic asset types could justifiably take precedence over an open market valuation. ${ }^{35}$ OECD (2018, p. 86) simply stated that valuation rules 'should be kept simple'.

Ultimately, the concern would be that a blanket rule imposing a particular method (market, income, or cost), open market valuation or formula for instance, and a set frequency (for instance, yearly) to valuation may result in administrative and compliance costs for particular asset types that, if not mirroring the charge to the annual wealth tax itself, may represent a large percentage of the overall value of the asset. In short, the costs could amount to a further 'effective' tax. We present rough estimates of the costs taxpayers may face in Section 4.

One option accordingly would be to use the figures for the valuation of assets that have been used in respect of discharging other liabilities. However, although the open market value is used for other taxes, it does not immediately follow that the valuations used there should always be used for a wealth tax, even if this would be administratively convenient. There may be manipulation that renders the figures unreliable. Take, for instance, the value that is placed upon assets for IHT. There is an incentive, when utilising business property relief, to place a high value on assets so as to reduce future CGT liability when the assets are sold. ${ }^{36}$ In this way an asset is transferred on death at an inflated value, meaning that the base cost for a future disposal is similarly inflated, thus reducing the future margin between the sale proceeds (or open market value) and the base cost. Using the same value for a wealth tax would, admittedly, push against this incentive, but how much would depend upon the differences between the liabilities under the taxes (and could result instead in assets being undervalued rather than overvalued).

(2) Time required to make a valuation. As noted above, Sandford et al. (1975, p. 161) argued that the choice of valuation methods in practice must be influenced by the need to reduce as much as possible delay in arriving at valuations. Adopting the market value rule in the case of IHT in the UK results in significant delays in all but the least complicated cases, as Troup, Barnett and Bullock (2020) note.

Ensuring that the valuation process is timely is linked to the importance of certainty in that people ought to know in as timely a manner as possible the extent of their liabilities, as noted by Sandford et al. (1975, p. 161). It is also linked to costs in that delays 'always increase administrative and compliance costs'. ${ }^{37}$

(3) Frequency. In order to reflect open market value, asset valuations would ideally be contemporaneous. However, this may not be practicable in respect of all asset types, as will be noted below. In the case of an annual wealth tax, care should be taken in order to ensure that the frequency of valuations is sufficient so that the values at least bear some resemblance to the current value of assets, unlike the situation that has occurred with council tax valuations in England, Scotland and Wales. ${ }^{38}$

Annual valuations can be expensive and time consuming, as can, to a lesser degree, one-time valuations for a one-off wealth tax. The OECD (2018, pp. 86-87) has suggested some other approaches that could simplify the process:

\footnotetext{
${ }^{35}$ Meade, 1978, p. 355.

${ }^{36}$ Pentelow, 2020.

${ }^{37}$ Sandford et al., 1975, p. 161.

${ }^{38}$ Mackie (2020).
} 
'In some cases, values for specific asset classes could be treated as fixed for a few years (e.g. France in the case of furniture, where estimated value is valid for three years). Alternatively, the value of taxpayers' total net wealth could be treated as fixed for a few years before being re-assessed (McDonnell, 2013).'

In the UK, ATED and the pre-owned asset tax ${ }^{39}$ provide examples of non-annual valuations used for certain tax purposes, with valuations required every five years. ${ }^{40}$ Where valuations take place at a particular date, such as 1 January in France ${ }^{41}$ and Norway ${ }^{42}$ or 31 December in Spain, ${ }^{43}$ it is important to appreciate that even yearly valuations may not always give an accurate reflection of value across the whole year, as these will only reflect the value of the assets at a particular time. Assets that are susceptible to severe fluctuations, such as start-up companies, ${ }^{44}$ may present problems in this respect. Intra-year fluctuations in a system of valuations at one point in a year as a result can give rise to undervaluations and overvaluations and hence lead to horizontal inequities. Given that different dates are already used, for instance, in respect of tax years and tax deadlines for individuals and companies in the UK, it could well be the case that different valuation dates are used for different classes of taxpayers. These different dates would lead to similar problems of consistency of treatment across taxpayers.

(4) Scalability. The method of valuation that is adopted ought to be one that feasibly can be applied at scale if the goal is to have a broad-based wealth tax (in terms of asset types). It is insufficient for a valuation method to be effective on a small scale but particularly costly, administratively complex or accessible only by a few (owing to a lack of professionally qualified valuers with expertise in valuation of certain assets, for instance).

\subsection{3 | Consistency}

ACS (p. 57) argue that neutrality and horizontal equity are highly important when it comes to a wealth tax. Consistency in the treatment of taxpayers in terms of the valuation of their assets, it follows, is similarly of great importance.

(1) Horizontal equity. This notion that the tax system should treat similar people in similar ways ${ }^{45}$ is generally taken to be an important consideration when designing tax rules, though it echoes also a thin conception of the rule of law, in that being ruled by law requires that the laws are equally applicable to all that fall within their scope. To that end, tax laws should not make unjustified distinctions between similarly placed taxpayers, although this of course raises the question of which are the relevant criteria for similarity. Certain valuation rules can fall foul of this goal, however, where they treat similar assets dissimilarly. To that end, it is interesting to note that the German Federal Constitutional Court ruled the valuation of assets subjected to the German wealth tax was unconstitutional because the valuation preferred immovable property over other forms of property, and this ruling played a key role in the eventual abolition of the tax. ${ }^{46}$

\footnotetext{
${ }^{39}$ See Finance Act 2004, Sch.15

${ }^{40}$ See further Pentelow (2020).

${ }^{41}$ Tirard, 2020.

42 Banoun, 2020.

${ }^{43}$ Ramallo, 2020.

${ }^{44}$ Ryan, 2020.

${ }^{45}$ Mirrlees et al., 2011, p. 34.

${ }^{46}$ Rehr, 2020.
} 
(2) Neutrality. A neutral tax system is one that treats similar activities in similar ways, which minimises distortion over people's choices and behaviour and thus minimises welfare loss. ${ }^{47}$ The Mirrlees Review emphasised 'the importance of neutrality as a benchmark' when designing taxes: '[w]hile we don't always want neutrality, it is often valuable and will always be an important benchmark for assessing the system' ${ }^{48}$ In the case of a wealth tax, the problem that could arise from having favourable rules for the valuation of particular assets, for instance, would be that people would shift their activities in response by investing in those favoured assets. ${ }^{49}$ As OECD (2018, p. 61) notes, and as will be discussed in more detail below, 'many categories of assets are exempt under net wealth taxes or benefit from reliefs or preferential valuation, which provides incentives to alter portfolio allocation away from that which would be optimal in a no-tax world'. Of course, for a credible one-off wealth tax, rather than an annual one, issues in respect of neutrality should not arise.

Neutrality and horizontal equity are often linked, in that a lack of treating persons, transactions and arrangements similarly can distort taxpayers' decisions. But neutrality follows from horizontal equity, and the latter is not a precondition of the former. Even where investment decisions are not distorted, or even before they become distorted, the fact of dissimilar treatment alone undermines equality before the law.

\subsubsection{Integrity}

It is desirable that the valuation methods hold up well when tension is applied. A fair measure of people's resources or their position relative to each other will not be provided without some account being taken of robustness to avoidance or the likelihood of legitimate disagreement.

(1) Robustness. Whilst it is 'likely that no tax is perfectly robust to planning', ${ }^{50}$ in order for taxes to be effective it is necessary that they are sufficiently robust to tax avoidance and planning. In the context of valuation for an annual wealth tax, there will necessarily be aspects which are open to gaming. For instance, the Meade Committee (1978, p. 356) highlighted the important issue of problems with taxpayers self-assessing the value of their assets:

'If taxpayers are required to value all their own assets with very little guidance other than the valuation should be "open market", a considerable burden of compliance costs is placed on the conscientious taxpayer and the way is open for much horizontal inequity between taxpayers of various degrees of integrity and for a decline in tax morality.'

Where valuation leads to a range of potential outcomes, they incentivise individuals to 'put forward figures which are right at the bottom end of any possible range of figures'. ${ }^{51}$ As Pentelow (2020, p. 6) stresses, in respect of open market valuation in the UK, the 'full range of situations cannot be captured within the legislative provisions and as a result the disputed valuation range can be very wide, not least because of the subjectivity of the assumptions which are necessarily used in any valuation'. This risk is particularly relevant when it comes to valuation of assets for a personal wealth tax, which may rely to a great extent on taxpayers' self-assessment of value

\footnotetext{
${ }^{47}$ Mirrlees et al., 2011, p. 40.

${ }^{48}$ Mirrlees et al., 2011, p. 45.

${ }^{49}$ Advani and Tarrant, 2021.

${ }^{50}$ Devereux and Vella, 2018, p. 477.

${ }^{51}$ Sandford et al., 1975, p. 175.
} 
and general compliance with the tax. For a one-off wealth tax in which taxpayers are deprived of tax-planning opportunities, the possibility to self-report low figures would still arise.

(2) Likelihood of disputes. Troup et al. (2020) propose that the likelihood that disputes could arise, where a value is attributed to an asset that departs from market value, should be taken into account when devising any valuation rules. It should go without saying that it would be undesirable if the exception proved more vexatious than the rule! The international background papers in the Wealth Tax Commission series frequently cite litigation over valuation as an issue under their wealth taxes. ${ }^{52}$ Banding reduces the scope for disputes in respect of ATED, and could similarly do so in respect of a wealth tax, but it does not eliminate disputes.

\subsection{Banding}

A 'banded' system of charges could be one administrative strategy for addressing valuation problems, as mentioned in ACS (pp. 58 and 60). Under such a system, the same charge would be applied to all taxpayers within each specified 'band' of total wealth, regardless of differences in their precise level of wealth within the band. Banding is already used in the UK in respect of ATED, wherein valuers need only to allocate an asset to a particular band of values rather than arriving at one specific value as is required for an ad valorem tax that is based on the precise value of whatever is being taxed. ${ }^{53}$ Banding can reduce the administrative imposition on taxpayers (and the tax authority), but at the cost of generating inequality within bands (by charging the same fee to taxpayers with potentially very different levels of wealth). The larger the possible range of valuations, the less effective a banding regime is at achieving this first outcome, as it is less likely to be able to capture individuals in the same range as their true wealth. Hughson (2020) discusses the possibility of a banded regime in much more detail.

Banding does not actually deviate from open market valuation, however; it requires, in the first instance, some plausible means of conducting an open market valuation exercise. What banding does accommodate is disagreements between HMRC and taxpayers as to what the open market value of an asset should be; it has the advantage of accommodating the inherent imprecision of valuation exercises $^{54}$ and thus reducing the scope for disputes. From a design perspective, banding still allows for the incorporation of progressive rates, as occurs in the case of ATED in the UK, although it effectively results in a cap on the maximum charge, which makes this approach regressive within the top band. ${ }^{5,56}$

As noted earlier, however, banding would only be useful where the scope for dispute about valuation is moderate. Where there is scope for significant differences, then banding becomes unhelpful. For instance, whereas residential property can be approximated within a narrow range, shares in unlisted start-up companies can reasonably be valued at significantly different amounts. When applied to multiple assets, significant differences may also arise such that banding is less useful; for instance, where there is a moderate range for a multitude of assets, meaning that the overall range is significant. For those whose total wealth falls just above the threshold for a band meanwhile, it creates gaming opportunities whereby taxpayers are incentivised to bunch below the threshold. Of course, for those whose total wealth falls somewhere near the mid or upper parts of a band, there is little incentive to undervalue - this is a serious virtue of a banding approach.

\footnotetext{
${ }^{52}$ See, for example, Rehr (2020) on Germany, and Vanvari and TA (2020) on India.

${ }^{53}$ Pentelow, 2020.

${ }^{54}$ Pentelow, 2020.

${ }^{55}$ See also Loutzenhiser and Mann (2021).

${ }^{56}$ Hughson (2020) discusses the difficulty of designing a banding scheme that has the wealthiest members of society paying anything more than a trivial effective rate of tax. An uncapped banding scheme maintains equity amongst those above the highest tax threshold, but forces them to value their wealth precisely.
} 
With respect to a wealth tax, a design question that arises is whether banding is used for the entirety of a person's wealth or whether it is simply used in respect of particularly difficult to value assets. As elaborated below, open market valuation only encounters serious difficulty with respect to certain asset classes, rather than in respect of wealth generally. To that end, if banding were to be proposed, it would seem more desirable at first that it should only be used in respect of those difficult to value assets. However, applying bands could drive taxpayers to vary their asset mix: taxpayers would have incentives to liquidate assets that would otherwise attract additional taxation and to re-invest them into other classes where any marginal increase in value (up to the band threshold) attracts no extra tax liability. Thus, it may violate the neutrality principle discussed in Section 2.4.

\section{3 | ASSET TYPES RAISING PARTICULAR VALUATION CONCERNS}

\section{1 | Pension rights}

Chamberlain (2021) describes the most common types of pensions typically found in the UK: defined contribution (DC) and defined benefit (DB) schemes. Essentially, under DC schemes, the benefits are determined by the accumulated contributions paid in, plus the actual return earned on investment, with the pension holder having considerable freedom to access the funds from age 55 - either withdrawing lump sums (up to 25 per cent tax-free, with further sums taxed at income tax rates) and/or purchasing an annuity. A DC fund can also be transferred at death. As Chamberlain notes, DC schemes are similar in structure to other forms of savings and portfolio investment, but with a tax-relief wrapper. Under DB schemes, however, benefits are generally contingent on factors such as length of service and salary level and begin to be paid from retirement age, typically 65. Importantly, as highlighted by Chamberlain, if the pension holder dies before reaching pensionable age, this generally gives rise to a death in service payment typically based on a simple multiple of salary. Other pensions (e.g. non-registered plans) are also used, along with other forms of deferred compensation arrangements including employee share schemes and options.

In this paper, we consider possible valuation approaches for pension rights, focusing on DC and DB pensions and especially on the more problematic DB pensions. The analysis draws on experience under other UK taxes, and particularly the lifetime allowance (LTA) for income tax purposes. Non-tax valuation situations are also considered. As noted in the discussion of this issue in Chamberlain (2021) and in Loutzenhiser and Mann (2021), pension rights have typically been fully exempted from current and historical wealth taxes, so this means that there is little international experience with pension valuation in this context to draw upon. Although ACS categorise pensions as 'easy to value', we argue here, and in Section 4, that that categorisation should be restricted to contribution-style pensions.

For personal income tax purposes, DB pensions are valued for the LTA with a crude formulaic approach approximated by taking 20 times the pension benefit payable plus a lump sum defined under the relevant pension scheme. ${ }^{57}$ According to Ramm and Eames, this value is likely to differ, oftentimes substantially, from more sophisticated methods of determining present value of the DB entitlements as personal characteristics are not considered and macroeconomic developments change over time. A variant of this approach is used for pension commutation. ${ }^{58}$

Various forms of primarily income-based approaches are used to value DB pensions for non-tax purposes including pension transfers and divorce. The valuation of pensions for divorce is explored for present purposes at some length as it provides useful insight into the practical difficulties involved in undertaking such valuations for a wealth tax. As described in detail in the report by the Pensions Advisory Group (2019, p. 30), valuations are used to divide pensions for divorce purposes according

\footnotetext{
${ }^{57}$ Ramm and Eames, 2020, citing Pensions Advisory Group, 2019.

${ }^{58}$ Ramm and Eames, 2020.
} 
to either the potential income value or capital value. A cash equivalent (CE) figure can be obtained from the pension provider to assist in this process. A particular form of $\mathrm{CE}$ figure, the cash equivalent transfer value (CETV), can also be determined for the purposes of transfers between pension schemes, and this method of valuation is the one ACS advocate. ${ }^{59}$ For a DB scheme, the CE is the value placed on the member's benefits by the scheme actuary, using assumptions such as future investment returns, inflation and life expectancies' ${ }^{60}$ However, CEs suffer from many limitations and may not be sufficient to achieve a fair outcome between the parties on divorce ${ }^{61}$ For example, if the DB pension is underfunded, this will reduce the $\mathrm{CE}$ figure such that it may not reliably reflect the value of the pension rights. ${ }^{62}$ Another option is to engage the services of a specialist Pensions on Divorce Expert (PODE). A PODE's opinion and valuation will take into account general assumptions (e.g. on inflation and mortality), along with individual scheme characteristics, which entails making assumptions on such factors as (a) the retirement age, (b) pension revaluation for DB schemes with final salary linking, (c) changes of pension benefits after retirement, (d) lump sum and commutation and (e) pension increase provisions. ${ }^{63}$ Further adding to the difficulty in this area, experts can disagree on the appropriate financial, economic and demographic assumptions to be used in the preparation of PODE reports as well as the appropriate valuation methodology. ${ }^{64}$ In summary, whilst DB pensions can be, and indeed often must be, valued for divorce purposes in order to achieve an outcome that is fair overall to both parties, it can be a highly complex, fact-dependent, contentious process requiring specialist skills. In our view, ACS underestimate these difficulties when they conclude that the most appropriate measure for the purposes of a wealth tax would be the CETV. ${ }^{65}$

How then should pension rights be valued for purposes of a wealth tax? The aim is 'to measure an individual's pension wealth "today", as opposed to the potential pension wealth on retirement' ${ }^{66}$ The present value of DC pension wealth is given by the value of the accumulated contributions in the pension pot plus the return earned on the investment, which is readily available and regularly reported to pension fund members. ${ }^{67}$ This is generally a straightforward cost approach to valuation. Although ACS broadly categorised pensions as easy-to-value financial assets, the determination of the present value of a particular individual's DB pension for a wealth tax is more problematic than for DC pensions, and it raises many of the same valuation issues just discussed in the non-tax contexts. As Ramm and Eames (2020, p. 3) argue '[i]n the context of a net wealth tax, the value of one's pension entitlement(s), or pension wealth, is given by the present value of the discounted future cash flows provided by the pension entitlement(s)'; in other words, adopting an income-based approach. However, DB pension valuation on an entitlement basis requires assumptions 'about the macroeconomic environment (including interest rates and inflation) and demographic developments (including mortality rate and retirement age) since contributions and benefits are relatively more unrelated' ${ }^{68}$ In theory, it would be preferable to use a more tailored valuation, based on assumptions that take into account the particular individual's circumstances and especially the expected lifespan of the holder and the holder's dependents. This presumably would require data on, for example, the individual's family history, medical history and lifestyle (e.g. whether they are a smoker or a drinker), which in practice would likely be too expensive, difficult or time-consuming to do. In summary, this

\footnotetext{
${ }^{59}$ Advani et al., 2020, p. 59.

${ }^{60}$ Pensions Advisory Group, 2019, p. 72.

${ }^{61}$ Pensions Advisory Group, 2019, para 6.11.

${ }^{62}$ Pensions Advisory Group, 2019, Appendix J.

${ }^{63}$ Pensions Advisory Group, 2019, Appendices O and Q.

${ }^{64}$ Pensions Advisory Group, 2019, Appendix O.

${ }^{65}$ Advani et al., 2020, p. 59.

${ }^{66}$ Ramm and Eames, 2020.

${ }^{67}$ Ramm and Eames, 2020.

${ }^{68}$ Ramm and Eames, 2020.
} 
leaves the valuation process, and the individual's tax charge, dependent on general demographic and macroeconomic assumptions, thereby raising horizontal equity issues should these general, broadbased assumptions not fairly reflect a particular individual's circumstances.

Alternatively, Saez and Zucman (2019a, p. 35) argued for a 'simple' approach to valuing DB pensions for wealth tax purposes: '[i]n the case of defined benefit pensions not yet in payment, the value of assets could be apportioned in proportion to the accrued benefits of each worker using simple formulas based on current salary, tenure, and age. The key requirement is that the total current value of each defined benefit fund should be distributed across beneficiaries.'

However, this valuation method eschews assessing the entitlement value of the DB for each individual (the ideal aim for a wealth tax) in favour of a method that effectively involves dividing up the assets of the underlying fund. Further, this may produce a low valuation where the DB scheme is underfunded; as already noted, a CE figure provided by the DB pension provider can suffer from the same limitation (and others).

In summary, valuation issues may explain in part why pension rights have been exempted from other wealth taxes, at least in respect of DB pensions, though liquidity, administrative and political reasons are also important concerns. However, a value of an individual's pension rights for wealth taxes can be arrived at using methods found under existing tax and non-tax situations. Valuation is relatively straightforward for DC pensions, which are similar in form to other types of savings and portfolio investment. DB pensions are more problematic. The valuation of a DB pension depends heavily on the valuation method chosen, which in turn can depend heavily on estimates of, for example, general economic factors and life expectancy. However, DB pensions can be valued by adopting either a crude measure such as that used for LTA purposes, a market transaction-based approach such as the CE approach with its inherent limitations as suggested by ACS, a more sophisticated market transactionbased model such as those used by specialists in the context of divorce, or with a Saez-Zucman approach based on apportioning the current value of the underlying DB scheme assets.

\section{2 | Primary residences and other non-agricultural property}

The 1974 Green Paper for a wealth tax included owner-occupied homes within the scope of the charge on the basis that '[t]hey are clearly realisable assets and their exemption would be unfair to those wealthy people who live in rented accommodation' ${ }^{69}$ and, in principle, proposed valuing owneroccupied homes at their market value. ${ }^{70}$ The Meade Committee took a similar position, focusing on equity reasons. ${ }^{71}$ Sandford et al. (1975, pp. 134-35) agreed that no exemption should be given for owner-occupied houses, again on equity grounds. They suggest this is a factor best taken into account in deciding on the threshold for the tax. ${ }^{72}$ Nevertheless, in European wealth taxes, primary residences typically have been eligible for some form of relief in the form of tax allowances or preferential valuation rules. As examples of the former, France offers a 30 per cent tax allowance and Spain offers an allowance up to EUR 300,000. ${ }^{73}$ On the latter, Switzerland taxes primary residences at 60 per cent of its market value and Norway values primary residences at a mere 25 per cent of their estimated market value; it should also be noted that both Switzerland and Norway have relatively low general exemption thresholds. ${ }^{74}$ Argentina exempts dwellings where the value does not exceed ARS 18 million (approximately $£ 200,000$ ). ${ }^{75}$ In Venezuela, a taxpayer’s house, if registered as their principal house

\footnotetext{
${ }^{69}$ HMSO, 1974, p. 9.

${ }^{70}$ HMSO, 1974, p. 14.

${ }^{71}$ Meade, 1978 , p. 354

${ }^{72}$ Sandford et al., 1975, p. 134

${ }^{73}$ OECD, 2018, p. 83.

${ }^{74}$ OECD, 2018, pp. 83-84.

${ }^{75}$ See IBFD Country Tax Guides, Argentina, para 5.1.2.
} 
before the tax administration, is an exempt asset. ${ }^{76}$ In contrast, primary residences were exempt under the Irish wealth tax. ${ }^{77}$ It is likely that the fairly widespread use of these reliefs is driven by political, historical, ideological and cultural factors, and possibly liquidity concerns, as opposed to concerns related to valuation.

When determining the open market value of property, there is a divergence of approach depending on the type of property. As noted by Mackie (2020, p. 9), 'for a commercial property investment, such as an office which is let to a tenant on a twenty-year lease with five yearly rent reviews, an income approach would be used to capitalise the rent received in order to arrive at an investment value for the property'. However, for a residential property investment for owner-occupation, 'it is likely to be a market approach which will be adopted, and whilst a certain number of factors are objective (such as size of house, number of bedrooms, size of plot etc.) there will be a greater emphasis on the application of subjective judgements by the valuer, particularly in the application of comparable sales where location, provision of local facilities, privacy, noise etc. can all play a part. ${ }^{78}$ A similar approach is adopted in other countries. For instance, in Norway, ${ }^{79}$ residential properties are normally valued based on calculated square metre prices (calculated in turn on the basis of statistics for residential properties sold in the area), whereas commercial property is calculated on the basis of an estimated letting value.

In the UK, property already needs to be valued for four categories of taxes: on transactions (CGT, IHT and stamp duty land tax (SDLT)), income (income tax/corporation tax), occupation (business rates and council tax) and ownership (ATED). ${ }^{80}$ Valuations of property for the purposes of CGT, IHT, SDLT and ATED are specifically covered in the Red Book under UK Valuation Practice Guidance Application (UK VPGA) $15 .{ }^{81}$ This Standard provides that the basis of value to be followed (generally a derivation of market value) is that as set out in each of the various statutes, as supplemented by case law, which elaborates upon the meaning of market value. ${ }^{82}$ For instance, in IRC v Crossman [1937] AC 26 it was held that for tax purposes what is considered is a hypothetical sale and not an actual one. Valuations of property for the purposes of taxes on income are required in myriad instances, such as when claiming capital allowances ${ }^{83}$ or for the purposes of tax on employment income where an employee receives an asset as part of a remuneration package. ${ }^{84}$ Complications arise where a higher value may be sought to be placed upon the property so that greater capital allowances may be claimed, which in turn would affect the tax payable on transactions such as SDLT. ${ }^{85}$ Business rates levied on non-domestic property, meanwhile, are calculated on the basis of rent that the property could have been let for on a certain date set out in law. Council tax, however, is based upon market value, albeit that in England and Scotland the value is based on the price that the property would have been sold for on the open market on 1 April 1991, and in Wales on 1 April 2003. These assessments are based upon a number of factors and there is scope for subjectivity and diversity of opinion.

Further, the availability of comparison websites (such as Zoopla and Rightmove) today, along with a more frequent valuation process, would likely reduce, but not eliminate, the scope for disagreement. These comparison websites helpfully identify comparable properties and provide information about recent sales and trends in the area. Further, these comparison websites pick up information from the

\footnotetext{
${ }^{76}$ See IBFD Country Tax Guides, Venezuela, para 5.1.

${ }^{77}$ Sandford and Morrissey, 1985, p. 22.

${ }^{78}$ Mackie, 2020, p. 9.

${ }^{79}$ Banoun, 2020.

${ }^{80}$ See Mackie (2020).

${ }^{81}$ Mackie, 2020.

${ }^{82}$ Mackie, 2020.

${ }^{83}$ See, for instance, CAA 2001 s.562(3)

${ }^{84}$ See, for instance, Income Tax Earnings and Pensions Act 2003, Pt. 3, Chapter 10, and Mackie (2020).

${ }^{85}$ Mackie, 2020.
} 
Land Registry on past transactions for the relevant properties themselves, which they can then index to attempt to reflect current market value. This information is invaluable for buyers and sellers, and by extension it would be useful for tax valuation purposes too. It should also be noted that ACS advocate having valuation of residential property conducted by the Valuation Office Agency (VOA) unless the taxpayer specifically requests to provide their own valuation. ${ }^{86}$ Thus, valuation cost would not ultimately be a problem for most individuals. However, as discussed in Section 4, a substantial share of individuals would be affected if the VOA were not to take this responsibility.

In summary, open market valuation works reasonably well in respect of primary residences and other non-agricultural property. Some disputes around valuation will be inevitable, for instance where the property is unusual or in some way unique. Though disputes arise frequently in respect of business rates, this has much to do with the mechanistic legal framework, which dictates how properties should be valued rather than problems with valuing per se. ${ }^{87}$ The issues that are presented by subjectivity in the valuation process would be significantly reduced if there were much more frequent valuations and hence significantly more data points for comparison, however. More advanced technology and algorithms today should also assist considerably.

\section{3 | Private business assets including shares in private companies}

The 1974 Green Paper recommended against exempting business assets from the tax base or offering specially favourable terms: '[t]he wealth tax would lose much of its desired social effect if a substantial proportion of those who are among the wealthiest in the country were not to come within its scope' ${ }^{88}$ Nevertheless, exemptions or some form of tax preferences for business assets are common under current and historical wealth taxes and have been justified on the basis of encouraging entrepreneurship and investment in productive assets. ${ }^{89}$ The Irish wealth tax provided a deduction of 20 per cent of the market value of 'productive assets' including business assets and shares in a trading company; the discount was 30 per cent for hotels. ${ }^{90}$ France and Spain provide exemptions for business assets, ${ }^{91}$ as does Algeria. ${ }^{92}$ Other countries have taxed them (for example Germany, Ireland, Luxembourg and Norway) but offered favourable tax treatment in the form of preferential valuation rules, the exemption of a proportion of assets, the exclusion of certain assets or a lower tax rate. ${ }^{93}$ In Argentina, resident companies are subject to the wealth tax, and shares in such companies are exempt from tax in the hands of shareholders. ${ }^{94}$

Starting from the assumptions that business assets should not be exempted from the tax base and should be valued for wealth tax purposes at open market value, it is worth recalling that open market values are already placed on business assets in the UK for tax purposes, such as for IHT on death, in respect of some inter vivos gifts and in relation to some trusts, and in respect of CGT for non-arm's length transactions, and for non-tax purposes, such as divorce, sales of businesses or shareholdings to third parties, shareholder litigation and accounting. ${ }^{95}$

A wealth tax on private business assets can give rise to difficult issues of valuation, however. In Section 4, shares of private companies are included in the 'hard-to-value' category of assets. These

\footnotetext{
${ }^{86}$ Advani et al., 2020, p. 59.

${ }^{87}$ Mackie, 2020, p. 16.

${ }^{88}$ HMSO, 1974, p. 11.

${ }^{89}$ OECD, 2018, p. 85.

${ }^{90}$ Sandford and Morrissey, 1985, p. 23.

${ }^{91}$ See OECD (2018, p. 83) and the respective IBFD Country Tax Guides.

${ }^{92}$ See IBFD Country Tax Guides, Algeria, para 4.1.

${ }^{93}$ OECD, 2018, p. 83.

${ }^{94}$ See IBFD Country Tax Guides, Argentina, paras 5.1.1 and 5.1.4.

${ }^{95}$ Nelder, 2020.
} 
issues do not arise so much in terms of larger companies (though of course extreme examples will arise where open market valuation is significantly contested), but principally in respect of the millions of UK smaller private companies and unincorporated businesses. ${ }^{96}$

Open market valuations for shares in quoted companies, for instance, can draw upon the quoted share price. $^{97}$ To that end, Regulation 2 of the Market Value of Shares, Securities and Strips Regulations 2015 provides that the market value of quoted shares shall be (on a day the Stock Exchange is open) the lower of two prices shown in the Stock Exchange Daily Official List for that day as the closing price for the shares, securities or strips on that day plus one-half of the difference between those two figures. When the Stock Exchange is closed, the value is calculated on the latest previous day on which it was open. In essence, for quoted shares, a market transactions approach to valuation can be adopted.

For unquoted businesses, open market valuation is computed by way of a comparability exercise, which is principally a market transactions approach (though the valuation requires reference to income). The value placed on a comparable company is determined through the use of benchmarks such as market capitalisation/profit after tax ('PAT') before then apportioning value to the relevant shareholding. ${ }^{98}$ These benchmarks, however, need to be adjusted to reflect market conditions in respect of relative risk and growth prospects of the companies being compared. Adjustment may also be required, according to Ryan (2020, p. 12), 'if the asset being valued is the whole of the business, or a controlling stake in a business, as capitalisation multiples derived from listed companies will incorporate a discount to reflect their minority status'. The calculation of this discount will in turn be dependent on the jurisdiction in which the listed shares are quoted - less of a discount in territories with strong minority shareholder protection, but more in jurisdictions with less shareholder protection. ${ }^{99}$ Saez and Zucman (2019a, p. 33) suggest that valuations for large private businesses can also draw on the 'financial system to put market values on many of [the] assets': '[1]arge private businesses (such as Uber or Lyft before their IPOs) are typically valued on secondary markets and their stock transactions are centrally registered'. Thus, open market valuation can be adopted for these larger private companies where information allowing for a comparability exercise is available.

The millions of smaller private businesses in the UK, however, present potentially a much greater problem in terms of determining open market value on account of a lack of information on the financial markets. If there are few or perhaps no direct comparable entities, then the comparability exercise will have to rely upon the valuer's judgements as to how the various assumptions should affect the value. Disputes between the taxpayer and the tax authority are inevitable, something that is borne out not just by the CGT and IHT case law on valuation of shares in private companies, but also by the differentiated nature of the outcomes in those cases, so heavily reliant as they are on the market conditions, the nature of the shareholding, and profit prospects of the businesses. ${ }^{100}$ Benchmarks such as PAT meanwhile are vulnerable insofar as they rely upon the assumption that past profits are a good guide to current value, which may or may not be the case.

Although ACS categorise shares of private companies as hard-to-value assets, they reduce the scope of this problem by characterising a large number of personal services companies as essentially deriving value from the owners' human capital. A similar approach could be taken to a large percentage of unincorporated businesses, which are also characterised as hard-to-value assets by ACS. This seems a reasonable approach because, according to the Business Population Estimates 2020 from the Department for Business, Energy \& Industrial Strategy, ${ }^{101}$ of the approximately six million private

\footnotetext{
${ }^{96}$ See Loutzenhiser and Mann (2021) and Advani et al. (2020, pp. 59-60).

${ }^{97}$ Ryan, 2020.

${ }^{98}$ Ryan, 2020.

${ }^{99}$ See Ryan (2020); see further Nelder (2020) on discount for lack of control (DLOC) and discount for lack of marketability (DLOM).

${ }^{100}$ See HMRC (2016).

${ }^{101}$ See https://www.gov.uk/government/statistics/business-population-estimates-2020.
} 
businesses in the UK, an estimated 76 per cent (comprising 3.3 million sole proprietorships, 946,000 companies and 311,000 ordinary partnerships) did not employ anyone aside from the owners. Under this approach, a large number of small private businesses could justifiably be excluded from concerns over valuation for a wealth tax, apart from the value attributed to tangible assets and intangible assets other than human capital, which can be assumed to be relatively low for many such businesses (see further Section 4).

Though a significant simplification, the exclusion of human capital may create some of its own issues. First, it would create a tension in the application of valuation rules across different but similar businesses. There may be closely held private businesses for which financial information about how they would be valued would actually be available, thereby allowing a comparability exercise to be undertaken, but which rely heavily upon the owners' human capital. Should the business then be valued using the ordinary comparability exercise or should human capital still be ignored? Either approach leads to a boundary between similarly placed businesses, thereby leading to inconsistency in treatment. Secondly, there is the issue of small private businesses that have more than one owner. Then the questions that emerge will be whether to exclude the human capital of all the owners or just that of the taxpayer whose wealth is being valued, and, if the latter, how to determine the value each owner brings to the business, which will not necessarily be proportional to their ownership interest.

By way of international comparison, Switzerland has adopted a formulaic method of valuing private businesses where open market value cannot easily be assessed. ${ }^{102}$ A company's value is determined by the combination of the weighted average of its 'earnings value', determined by capitalising the adjusted average net profit of the last two or three years with a capitalisation rate, and its book value. Holding companies or property companies, meanwhile, are valued based on the net asset value of the underlying assets. ${ }^{103}$ Saez and Zucman (2019a, p. 33) favourably cite the use of this approach, underlining the fact that the use of formulae avoids the need for yearly costly valuations. There are obvious flaws in the Swiss approach, however, such as the reliance that it places upon profits (thus leaving open the problem of valuing loss-making companies ${ }^{104}$ ) and the inequities across different industries that result from the use of a uniform capitalisation rate. ${ }^{105}$ Further, it assumes, indiscriminately, that past profits are a good guide to current value when the reality is that such an assumption will only hold in selected cases (a problem encountered also in using an open market valuation approach to small, private companies). Book values, meanwhile, are problematic as they may reflect not current asset values but rather the original cost, intangible assets may not be recorded and, in the case of distressed companies, would overstate the amount that the assets would likely fetch on sale. ${ }^{106}$ Whilst a cost approach can be a legitimate approach for determining open market value, the book value approach here does not incorporate fully the cost of replacing the assets. In short, a formula that combines earnings and book values is a crude means of determining value and should properly be understood as a departure from open market valuation, as it is not geared to the assumptions that underpin open market valuation. Policymakers accordingly should be aware that whilst a formulaic approach to valuing businesses is beneficial in terms of certainty for taxpayers and feasibility, it falls short in terms of consistency and integrity.

Issues also arise in respect of valuing particular businesses assets, such as intellectual property. Market implied transaction prices can be used as the basis for valuing the intangible asset, but the problem is that 'the number of benchmark prices that can be obtained is still limited' ${ }^{107}$ Even where reliable benchmarks are available, the 'characteristics of IP assets vary considerably' such that 'it

\footnotetext{
${ }^{102}$ See Eckert and Aebi (2020); see further Nelder (2020).

${ }^{103}$ See also Tirard (2020).

${ }^{104}$ Nelder, 2020.

${ }^{105}$ Eckert and Aebi, 2020.

${ }^{106}$ Ryan, 2020.

${ }^{107}$ Ryan, 2020.
} 
is hard to adjust benchmark values to reflect the differences between the different assets' and are context dependent such that 'care must be exercised when using a benchmark value for an intangible asset, as the price paid in one context may not be representative of the value of the same asset in a different context'. ${ }^{108}$ The result is that disputes with tax authorities about valuation are inevitable, as is seen in the parallel context of valuation of intellectual property for transfer pricing. It is not just the transactions-based approach to valuing assets that comes into difficulty with some business assets. The income approach struggles when dealing with long-lived or indefinite-lived assets. Measuring value using a discounted cash flow method here can give rise to disputes given that various choices have to be made by the valuer: the type of cash flow (e.g. pre-tax or post-tax, total cash flows or cash flows to equity, real or nominal, etc), the most appropriate period over which the cash flow will be forecast, whether there is a terminal value, the determination of any such terminal value and the appropriate discount rate. 109

Could an option for paying the wealth tax in specie deal with valuation disputes with respect to private company shares in particular? Saez and Zucman (2019a, 2019b) advocate the option of payment in specie for their wealth tax on billionaires as an option to address valuation disputes (and also liquidity concerns ${ }^{110}$ ). For example, if a taxpayer has other assets in excess of the wealth tax exemption threshold, and is firmly in the top tax rate band of the tax (e.g. 2 per cent), then if there is a disagreement on whether the taxpayer's shares in a private business are worth $£ 50$ million or $£ 100$ million, the disagreement can be solved by the payment in specie of 2 per cent of the shares. The government can then decide whether to hold on to its 2 per cent shareholding and perhaps look to increase its shareholding year-on-year or sell the shares to the highest bidder. Importantly, this would not alleviate the need to value the shareholding for other purposes, notably CGT in respect of the transfer, which greatly undermines the supposed positive benefits of in specie payments in terms of minimising valuation issues. Moreover, Saez and Zucman (2019a, pp. 33-34) have in mind a large exemption threshold so their focus is on a relatively small number of taxpayers (c.75,000 families) and thus a small number of very valuable private businesses (e.g. Cargill or an unprofitable but highly valuable start-up). It is highly questionable whether their approach could be scaled up for a larger number of private businesses in the UK.

What follows from the above is that, as a starting point, open market valuation should be adopted generally in respect of valuing business assets. For shares in unquoted large businesses, professional valuations at the level of the business as opposed to at the shareholder level could be obtained (see also Section 4 on costs). Whilst other business assets such as intellectual property and long-lived assets may be difficult to value, professional valuers there too can be relied upon and it is not suggested that it is infeasible to provide an open market value for these assets.

Deviations from this general approach will be necessary for difficult-to-value private businesses, principally smaller private businesses for which the financial markets do not provide information. In specie transfers do not present a readily available fix to the issues in respect of smaller private businesses. Instead, a simplified approach to valuing large numbers of private businesses such as personal services companies and unincorporated businesses, which excludes value attributed to the owners' human capital but includes the value of tangible and intangible business assets other than human capital, has the potential to greatly reduce the scope for valuation issues. It is appreciated, however, that this would create its own issues: it would need to be determined, first, whether there is in fact insufficient information to conduct an open market valuation (which would likely lead to disputes about whether a comparability exercise is indeed possible). There is no ready-made solution to this issue and it would instead need to be accepted that such disputes would arise. It is worth recalling, however, that boundaries are innumerable in the tax code and the perfect should not be allowed to

\footnotetext{
${ }^{108}$ Ryan, 2020, p. 16.

${ }^{109}$ See IVSC, 2019, pp. 37-38.

${ }^{110}$ See Loutzenhiser and Mann (2021) and Meade, 1978, p. 360.
} 
be the enemy of the good. What is important is whether the presence of such a boundary (and, as such, the deviation from open market valuation) would undermine certainty, feasibility, consistency and integrity more than the exclusion of such a boundary. Whilst each criterion will be compromised by either approach, it seems on balance that the presence of a boundary is less compromising than its removal. Once a boundary has been set in law, which approach is appropriate will be a matter ultimately to be hashed out between taxpayers and the tax authority, and then, if necessary, before the courts. Secondly, and it would need to be determined, in the case of businesses with more than one owner, whether to exclude all human capital. Again, human capital should only be excluded for those cases where there is insufficient information available (otherwise the perverse outcome would be that large accounting firms and law firms might have little or no 'value'). Here, for businesses with more than one owner meanwhile, human capital of all of the owners, rather than just one, should be excluded.

Alternatively, rather than ignoring human capital, a formula based on book value, as adopted in Switzerland, seems a plausible option for valuing smaller private businesses. Such a formula provides certainty for taxpayers, is administratively efficient, is unlikely to lead to significant disputes, is quick, scalable and comes generally with frequent valuations, albeit at a large cost in terms of horizontal equity and neutrality (with undervaluations and overvaluations) and robustness (with the ability to game values). It must be stressed also that it is an incredibly crude method for determining value. Given this, our preference would be for the approach that excludes human capital.

So, in short, our recommendation would be open market valuation generally (including for large private businesses where open market valuation is not overly difficult or costly because sufficient information exists), with values excluding human capital for smaller businesses where open market valuation is infeasible. It is appreciated that this will lead to boundary disputes, but such boundaries are not a reason in itself to reject this recommendation.

\subsection{Agricultural property}

As discussed in more detail in Loutzenhiser and Mann (2021), commentators including Sandford et al. (1975) and Meade et al. (2011), as well as the 1974 Green Paper, generally recommend against exempting agricultural property from the wealth tax base or offering especially favourable terms. However, Sandford et al. (1975, p. 229) recommended a 'cautious' valuation of agricultural property under a wealth tax as well as the possibility of a ceiling on the tax. OECD (2018, p. 84) briefly notes that agricultural assets have tended to benefit from preferential tax treatment under European wealth taxes. France includes agriculture in its exemption for businesses. ${ }^{111}$ Under the Irish wealth tax, agricultural property and fishing boats were eligible for a deduction of the lesser of 50 per cent of market value or $£ 100,000 .{ }^{112}$ Sandford et al. (1975, p. 79) described the then German wealth tax as using a separate basis of assessment for agricultural property tied to potential yield and a special DM 100,000 allowance was granted for certain entities that engaged in agriculture and forestry. ${ }^{113}$ India excluded agricultural assets from its wealth tax. ${ }^{114}$ In Argentina, non-urban land owned by individuals is exempt from the wealth tax. ${ }^{115}$ However, as with exemptions for primary residences and business assets, such broad exemptions and reliefs are difficult to justify on tax policy grounds in general and as a solution to valuation concerns in particular.

\footnotetext{
${ }^{111}$ Dupas, 2020.

${ }^{112}$ Sandford and Morrissey 1985, p. 22.

${ }^{113}$ Rehr, 2020.

${ }^{114}$ Vanvari and TA, 2020.

${ }^{115}$ See IBFD Country Tax Guides.
} 
In the context of advocating replacing business rates with a land valuation tax (LVT), the Mirrlees Review argued that agricultural property should be in the LVT base. ${ }^{116}$ It assessed the practical challenges of valuing land generally for LVT and concluded that the exercise was formidable but possible, because a considerable machinery already existed to value land for business rates, these valuations were updated regularly, and the Land Registry held considerable information about property boundaries that could be used to generate information on land areas. ${ }^{117}$ In the Review, Mirrlees et al. (2011, p. 374) highlighted that the biggest practical obstacle to the implementation of an LVT was that it would require the valuation of land separate from any structure on it - though that may be less of an issue for agricultural land. They suggested that it would be possible to determine the value per acre of land given a reasonable body of land transactions, current estimates already published by the VOA (and disaggregated by local area), recognised methods for valuation, and considerable international experience of land valuation, including in Denmark and in various US and Australian states. ${ }^{118}$ The Review ultimately concluded that a recent review of US evidence suggested that successfully implementing and administering an LVT was feasible. However, the Review refrained from making a judgement on feasibility for the UK, proposing instead that the government should study the feasibility of such a tax, starting with commercial and agricultural land. ${ }^{119}$

In general, open market valuation should work reasonably well in respect of agricultural property - as for primary residences and other non-agricultural property - adopting principally a market transactions approach, which utilises the considerable market information that is available. However, experts may need to play a more significant role for agricultural property. ${ }^{120}$ Notably, the courts have been called upon to consider the extent to which hypothetical development potential should affect the valuation of such property. According to Clark and $\mathrm{Fu}$, the courts have consistently found that this 'hope value' needs to be taken into account in any assessment of market value. Further, the courts have favoured a 'top-down' approach, pursuant to which the land value is determined first, assuming relevant planning permission has been granted, and then this figure is reduced to reflect the relative likelihood of planning permission being granted. ${ }^{121}$

In summary, notwithstanding historic and current international practice, the preferred valuation for agricultural property is open market value. Preferential treatment for agricultural property appears to be driven more by political considerations and liquidity concerns than by difficulties with valuation. We agree with the Mirrlees Review that a considerable machinery already exists for valuing land, and this could be extended to cover agricultural property not already included.

\subsection{Art, antiques and other heritage assets}

As with the other problematic asset types discussed so far, artwork and antiques are often exempt from European net wealth taxes, in this case on the basis that they are difficult to value but also to help protect national heritage. ${ }^{122}$ The 1974 Green Paper was broadly in favour of taxing such assets, but recognised that it could lead to the dispersal of the national heritage and floated the possibilities of deferral of tax or special arrangements conditional on public access, perhaps in combination with arrangements to take the works into public ownership in satisfaction of accrued tax liabilities. ${ }^{123}$

\footnotetext{
${ }^{116}$ Mirrlees et al., 2011, p. 377.

${ }^{117}$ Mirrlees et al., 2011, p. 374.

${ }^{118}$ Mirrlees et al., 2011, p. 375; Boadway et al., 2010, p. 805; Clark and Fu, 2020.

${ }^{119}$ Mirrlees et al., 2011, p. 375.

${ }^{120}$ Clark and Fu, 2020.

${ }^{121}$ Clark and Fu, 2020, citing Foster v HMRC [2019] UKUT 251 (LC).

122 OECD, 2018, p. 83.

${ }^{123}$ HMSO, 1974, pp. 11-12.
} 
Boadway, Chamberlain and Emmerson (2010, pp. 783-84) raised similar concerns and suggested similar special arrangements. Sandford et al. (1975, p. 239) recommended exemption from wealth tax for such assets, if combined with appropriate conditions of public access. They noted that at that time Denmark, Sweden and the Netherlands completely exempted works of art. Germany and Norway taxed art but Sandford et al. (1975, p. 237) had the 'strong impression' that there was much undetected under-reporting and undervaluation of works of art.

Proceeding on the assumption that such assets should be included in the wealth tax base, ${ }^{124}$ there are a number of different valuation methods that can be deployed in order to determine the open market value of artwork. Put at its simplest, 'the valuation of works of art is not a precise science', with the process often giving rise to a range of acceptable values which 'competent valuers would recognise as the price that property would fetch if sold on the open market'. ${ }^{125}$ Common practice is for valuers to set out a range of values (known as 'current auction estimates') for a work of art, with the lowest value in the range being the 'low auction estimate', the highest being the 'high auction estimate' and the median being the 'mid auction estimate'. ${ }^{126}$

The fact that valuing chattels such as art is an inexact science, however, should not be used to overstate the difficulties in valuation. The market is reasonably well informed. Purchasers are knowledgeable about art-historical considerations and prices. Information about auctions is widely reported. ${ }^{127}$ Following from these considerations, a market transactions approach for determining open market valuation would be appropriate. Further, art, antiques and other heritage works come within the scope of UK taxation in respect of CGT, IHT and income tax, and the relevant statutory provisions all refer to open market value. ${ }^{128}$ It is generally accepted that a fair open market value for those taxes is equivalent to current mid auction estimate. ${ }^{129}$ This is principally on account of the judgment of Ungoed-Thomas in Re Hayes' Will Trusts [1971] 1 WLR 758 wherein he explained this basis of valuation as follows:

'It has been established time and again in these courts, as it was in our case, that there is a range of price, in some circumstances wide, which competent valuers would recognise as the price which "property would fetch if sold on the open market". Neither the section [7(5) Finance Act 1894] nor Sankey J. [in Earl of Ellesmere v Inland Revenue Commissioners [1918] 2 KB 735] requires that the top price of that range should be the price fixed for estate duty. That price, together with the lowest price in the range, may be expected to be the least likely price within the range, to be obtained from the open market. The most likely price, in the absence of consultation between the valuer representing conflicting interests, would presumably be the mean price.'

Whilst the mid auction price would mirror what is already used for UK tax purposes, these valuations do not take place annually or even frequently but only on specific taxable events. An annual wealth tax would require more frequent valuations. A solution to this problem lies in relying on the Art Market Research indices, which are a sort of 'RPI' for art and are already used by HMRC. ${ }^{130}$ Thus, the Art Market Research indices, along with other databases of past sales such as ArtNet, could operate within the scheme for valuation in a similar way to that of comparison sites such as Zoopla for property.

However, a final remark should be made about insurance values. As noted above, OECD (2018, p. 86) suggested insured values could be used for assets such as artwork and high-value jewellery, which are infrequently traded and therefore hard to value. Saez and Zucman (2019a, p. 35) also

\footnotetext{
${ }^{124}$ See also Advani et al., 2020, pp. 52-53.

125 Tennant, 2020, p. 3.

126 Tennant, 2020.

${ }^{127}$ Tennant, 2020.

${ }^{128}$ See further Tennant (2020).

${ }^{129}$ Tennant, 2020.

${ }^{130}$ Tennant, 2020.
} 
suggested insurance values for art and other valuables would be 'usable'. These valuations would be readily available, thereby reducing compliance and administrative costs. They are also independently verified by parties, namely insurance firms, with an interest in ensuring an appropriate value is placed upon the assets, thus rendering the figures relatively robust to abuse or gaming. However, the suggestion to use insurance values overlooks the fact that different values are used depending on the purpose of the valuation - whether the owner, for instance, wishes to be compensated or to replace the asset. If the owner wished to replace any totally lost item by purchasing something comparable at auction, the value would be double the low auction estimate. ${ }^{131}$ This is critical and, as a result, insurance that is taken out to replace assets will typically far exceed what the asset itself would fetch on an open market, as the amount also takes into account transaction costs, such as commission and other taxes and fees of a replacement. It is incorrect to believe that insurance values reflect open market values; they may even far exceed them.

In short, while it is not necessary to depart from open market valuation in respect of art, antiques and other heritage items may be more problematic. Insurance values could be used, as doing so would be justified by reference to the principles of certainty, feasibility and integrity, though this undermines consistency. Policymakers in short would need to balance the difficulty and cost in arriving at a value using open market valuation as against the horizontal inequity caused by using insurance values. Using our crude estimates in Section 4, it would seem that using open market valuation even in respect of those hard-to-value antiques and other valuables is plausible, so it is tentatively suggested that open market valuation ought to be used for them too.

\section{4 | COSTS OF VALUATION}

This paper has so far highlighted the many challenging issues in establishing the value of certain assets for tax purposes. While the number of potential problem areas is large, a clear-eyed analysis also requires information on their aggregate scale - in particular, a sense of the number of taxpayers likely to be grappling with these issues, and how much of a financial imposition the need to precisely value their wealth would be.

In this section, we develop rough estimates of the costs taxpayers may face in establishing a precise estimate of their total wealth, broadly following the wealth tax design laid out by ACS. We focus on the costs to taxpayers of professional assistance with valuing their assets; other compliance costs to taxpayers that are not accounted for in these estimates include the cost (paid or in their own time) of filing returns, the cost of valuing any assets themselves where they do not seek professional assistance, and potentially the costs of further engagement with the tax authority, including any disputes and litigation. We also do not take into account here the costs to external agencies (including the VOA and pension funds) of completing valuations on certain assets, even though these are likely to be substantial; estimates of the costs to government authorities are given by Advani, Hughson and Tarrant (2021).

Even given the limited scope, this is likely to be a contentious exercise. As noted by Pentelow (2020), valuations for individual assets are often given as a range rather than a precise point estimate, as may be needed for a wealth tax. Information on valuation costs must be imputed from other policies, and the data do not allow a particularly nuanced approach, as explored below, requiring heavy application of assumptions. However, the aggregate costs to taxpayers of complying with a tax should be a policy consideration, so this is important, if approximate and preliminary, work.

${ }^{131}$ Tennant, 2020. 
TA B L E 1 Classification of assets according to difficulty of valuation

\begin{tabular}{|c|c|c|c|}
\hline & Pentelow (2020) & Wealth tax design (ACS) & WAS treatment \\
\hline Easy & $\begin{array}{l}\text { Savings } \\
\text { Listed shares } \\
\text { Other securities } \\
\text { Pensions }\end{array}$ & $\begin{array}{l}\text { Pensions valued by pension } \\
\text { funds; otherwise, taxpayer's } \\
\text { responsibility to value }\end{array}$ & $\begin{array}{l}\text { Net financial wealth (excl. some } \\
\text { unlisted shares) } \\
\text { Mortgage endowments } \\
\text { Contribution-style pension } \\
\text { wealth }^{\mathrm{b}} \\
\text { Vehicles }\end{array}$ \\
\hline Mid & $\begin{array}{l}\text { Residential property } \\
\text { Commercial property } \\
\text { Most agricultural land }\end{array}$ & $\begin{array}{l}\text { Pensions valued by pension } \\
\text { funds; otherwise, valued by } \\
\text { VOA }\end{array}$ & $\begin{array}{l}\text { Net property wealth (excl. UK } \\
\text { and overseas land) } \\
\text { Benefit-style pension wealth }\end{array}$ \\
\hline Hard & $\begin{array}{l}\text { Shares in private companies } \\
\text { Intellectual and other } \\
\text { intangible property } \\
\text { Unincorporated businesses } \\
\text { Land with 'hope value' for } \\
\text { development } \\
\text { Collectibles such as fine art }\end{array}$ & $\begin{array}{l}\text { Taxpayer's responsibility to value } \\
\text { (likely to need professional } \\
\text { valuation) }\end{array}$ & $\begin{array}{l}\text { Business wealth (incl. shares in } \\
\text { own business) } \\
\text { Unlisted shares }^{\mathrm{a}} \\
\text { Land wealth }^{\mathrm{c}} \\
\text { Collectables and valuables }\end{array}$ \\
\hline Excluded & & $\begin{array}{l}\text { De minimis exemption for } \\
\text { individuals’ items worth less } \\
\text { than } £ 3,000\end{array}$ & $\begin{array}{l}\text { Any asset categories worth less } \\
\text { than } £ 3,000 \\
\text { All household contents }{ }^{\mathrm{d}}\end{array}$ \\
\hline
\end{tabular}

Note: a Arm's length retail shares cannot be properly disentangled from private equity investments; shares held by individuals with only unlisted UK shares are included as hard-to-value assets, and all other shareholdings are treated as easy to value. ${ }^{\mathrm{b}}$ Split of pensions into DB pension and other follows from Section 3.1 but is not suggested by Pentelow. Benefit-style pension wealth includes the value of pensions in payment (this may include some DC pensions in payment, which are not separately identified in the WAS); contribution-style pension wealth includes DC and any other pension pots. ${ }^{\mathrm{c}}$ No information is given on development prospects of land value in the WAS; however, land without buildings is not expected to be valued by the VOA under the ACS wealth tax design. Property assets reported in the WAS should exclude any commercial property, which should be reported as a business asset. ${ }^{\mathrm{d}}$ Advani et al. (2021) present evidence suggesting that the majority of household contents items will be exempt from a wealth tax with a $£ 3,000$ de minimis.

Source: Pentelow (2020); Advani et al. (2020).

\subsection{Which assets would require individual professional valuation?}

Based on the discussion earlier in this paper and in Pentelow (2020), we examine the asset types reported in the Wealth and Asset Survey (WAS), ${ }^{132,133}$ broadly classifying each into categories according to how difficult they are to value (Table 1). Assets which are considered fairly easy to value include most financial assets, which are liquid and/or for which methods of valuation already exist for other tax or legal purposes. More uncertainty is likely to exist around valuations of property and most agricultural land: as mentioned above, in ACS's design this is addressed by having the VOA responsible for valuation of these assets (a role it largely already fulfils), meaning the costs for valuing these assets are not directly imposed on the taxpayer. As noted earlier, we consider only DC pensions to be easy to value; even so the cost of placing a value on any pension entitlement is borne by pension funds in ACS's design.

The hard-to-value assets are of most interest, including the 'problematic' asset types mentioned earlier in this paper and in Pentelow (2020). Some assets do not have a precise equivalent in the WAS data: for example, commercial property could be recorded as a business asset or as a personal asset,

\footnotetext{
${ }^{132}$ This section uses data collected in 2016-18 from the Office for National Statistics (ONS) Wealth and Assets Survey (WAS), the most comprehensive data source on wealth in the UK. Advani et al. (2021) provide a full account of relevant aspects of these data and how they are adjusted for the present purposes. In particular: the data are intended to represent private households in Great Britain and exclude individuals in Northern Ireland and the area north of the Caledonian Canal, as well as individuals living in institutional settings; the reported value of household contents is excluded from most calculations, on the basis that their open market value is unlikely to be more than $£ 3,000$, the recommended de minimis exemption in ACS; the business wealth and share wealth holdings of individuals with over $£ 500,000$ in total wealth has been boosted to fit the amount of wealth which is likely not to be captured at the top of the distribution.

${ }^{133}$ ONS, Social Survey Division, 2020.
} 
depending on how the respondent answers the survey questions (all personal property is included in the 'mid' difficulty tier, while all business assets are 'hard'). Acknowledging that this will be a very imprecise exercise, we nonetheless attempt to implement this classification at a broad level. The remainder of this section covers specific choices around classifying WAS asset categories as hard-tovalue (or not), and the effect of de minimis exemptions as recommended in ACS.

\subsubsection{Unlisted shares and private companies}

In the WAS, the values of listed and unlisted shares an individual owns are not reported separately. If individuals report owning only listed or unlisted UK shares (as opposed to both, and/or any shares held overseas), these can be easily allocated; however, we have no way to disentangle this information for individuals who report owning more than one type of share. Moreover, UK unlisted shares could include both retail shares held at arm's length, such as those listed on the Alternative Investment Market (AIM), and private equity investments; this is a key distinction of interest for the purposes of ease of valuation.

The approach taken here is to include the value of shares held by individuals who own only unlisted shares in their hard-to-value assets; otherwise, share holdings are all assumed to be easy to value. ${ }^{134}$ As a result, we will classify some unlisted (private equity) share investments as easy-to-value assets, if the holder also has listed shares; at the same time, some unlisted shareholdings that we do allocate to the hard-to-value category will likely include retail unlisted shares, which should be easy to value. On balance of probabilities, we suspect this may slightly overestimate the share of hard-to-value assets.

\subsection{2 | Business wealth}

The many challenges in valuing businesses are described earlier in this paper. In the absence of a (Swiss-style) formula-based approach, businesses for which the financial market information typically used for valuation purposes does not exist are likely to present a particular challenge. However, as noted above, it may be the case that some small businesses, especially those that are owned and managed by one or two people and have no other employees, are less likely to present valuation problems (see Section 3.3). ${ }^{135}$ For example, personal service companies essentially provide a corporate structure for an individual to work in much the same way a self-employed person might, but with different tax implications.

Work carried out by the Institute for Fiscal Studies (IFS) shows that there has been a substantial rise in such companies over the past decade, such that small, closely held businesses now make up a large share of all companies. ${ }^{136}$ For example, around one-third of owner-managed companies in the business services industry were owner-managed companies with a single director, and another third had two directors. Cribb et al. also provide evidence suggesting that profits of many closely held businesses tend simply to be a return on the labour of the owner-manager, particularly in industries such as business services, financial services and medicine; these businesses tend not to have employees or undertake substantial investment. As the ACS tax design excludes the value of the owner's own

\footnotetext{
${ }^{134}$ Shares that individuals hold in their own businesses should be reported as business assets.

${ }^{135}$ The WAS survey asks respondents to 'include the value of financial assets, accounts receivable, inventories, land, property, machinery, equipment, customer lists and intangible assets' in their estimate of the value of their business; while this list includes many of the more complex assets that will be difficult to value, such as intellectual and intangible property or land with development value, it will not be the case that all those reporting owning business assets will have these complex assets and will require valuations. Note the survey indicates elsewhere that the response to this question should not include any shares held at arm's length, but be limited to the business assets over which the respondent exerts direct control.

${ }^{136}$ Cribb, Miller and Pope, 2019.
} 
TA B L E 2 Individuals with business assets by total value of business assets

\begin{tabular}{l|l}
\hline Range & Number of individuals (in thousands) \\
\hline$£ 0-3 \mathrm{k}$ & 696 \\
$£ 3-10 \mathrm{k}$ & 527 \\
$£ 10-20 \mathrm{k}$ & 221 \\
$£ 20-50 \mathrm{k}$ & 366 \\
$£ 50-100 \mathrm{k}$ & 208 \\
$£ 100-250 \mathrm{k}$ & 184 \\
$£ 250-500 \mathrm{k}$ & 151 \\
$£ 500 \mathrm{k}-1 \mathrm{~m}$ & 111 \\
$£ 1-2 \mathrm{~m}$ & 50 \\
$£ 2-5 \mathrm{~m}$ & 29 \\
$£ 5 \mathrm{~m}+$ & 25 \\
Total & 2,566 \\
\hline
\end{tabular}

Note: Businesses with total assets less than $£ 3,000$ are not chargeable under the wealth tax design.

Source: Authors' calculations based on the WAS, 2016-18.

human capital from the chargeable tax base, such businesses are likely to have little or no marketable value beyond the resale value of tangible assets, such as tools or equipment.

It follows that we should separate, for example, personal service companies from larger or more complex businesses whose sale would involve the transfer of intellectual property and intangible assets, as only the latter would be likely to need professional valuation for the purposes of a wealth tax. Unfortunately, the WAS questions do not facilitate the drawing of such a distinction. We include all business wealth over the de minimis amount as hard to value in valuation cost estimates, but note that valuation costs as estimated will include costs of many businesses that do not have much marketable value and may in fact be easy to value.

While the size of the business is an admittedly poor approximation of this distinction, Table 2 shows that 85 per cent of all individuals who report having business assets estimate that those assets are worth less than $£ 250,000$ - not enough in itself to make someone liable for a wealth tax at any likely minimum threshold.

\subsection{3 | Pension wealth}

Although, as noted by Pentelow (2020), DB pensions typically have a transfer value, the discussion in Section 3.1 notes the challenges inherent in applying such an approach to valuation. We prefer to split 'benefit-style' pension wealth (i.e. wealth associated with DB pensions) from the easier-to-value 'contribution-style' pension wealth, including DC pensions, additional voluntary contribution (AVC), and personal pensions.

This distinction, unfortunately, does not translate well to the WAS data. Most significantly, it is not possible to distinguish DC pensions in payment from DB pensions in payment; therefore, we have included all pensions in payment as benefit-style pension wealth, while all other pension wealth is treated as contribution-style wealth. It is worth noting, in addition, that the WAS data on which our calculations must rely are themselves estimates, and are subject to the same challenges we discuss in Section 3.1: the value of DB pension wealth is calculated by estimating the size of a DC pot that would be needed to purchase an annuity generating the same income stream (and lump sum) as the DB pension. 
TA B L E 3 Effect of de minimis exemptions on chargeable wealth

\begin{tabular}{|c|c|c|c|}
\hline & $\begin{array}{l}\text { Number of individuals } \\
\text { with positive net wealth } \\
\text { (in thousands) }\end{array}$ & $\begin{array}{l}\text { Share of which } \\
>£ 3,000(\%)\end{array}$ & 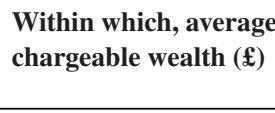 \\
\hline \multicolumn{4}{|l|}{ Easy to value } \\
\hline $\begin{array}{l}\text { Financial assets excl. } \\
\text { shares }\end{array}$ & 39,682 & $*$ & 38,311 \\
\hline Vehicles & 34,288 & 65 & 9,474 \\
\hline $\begin{array}{l}\text { Contribution-style } \\
\text { pensions }\end{array}$ & 23,997 & 44 & 74,853 \\
\hline Shares excl. some unlisted & 5,716 & $*$ & 42,874 \\
\hline Number plates & 3,732 & 7 & 4,010 \\
\hline \multicolumn{4}{|l|}{ Mid difficulty } \\
\hline Property & 29,248 & 99.9 & 173,663 \\
\hline Benefit-style pensions & 22,037 & 97 & 248,733 \\
\hline \multicolumn{4}{|l|}{ Hard to value } \\
\hline Collectables and valuables & 5,753 & 70 & 14,007 \\
\hline Business assets & 2,566 & 73 & 377,281 \\
\hline Overseas land & 917 & 94 & 100,486 \\
\hline UK land & 307 & 89 & 231,011 \\
\hline Unlisted shares & 135 & $*$ & 87,378 \\
\hline
\end{tabular}

Note: Benefit-style pension wealth includes the value of pensions in payment (this may include some DC pensions in payment, which are not separately identified in the WAS); contribution-style pension wealth includes DC and any other pension pots. Unlisted shares based on individuals with only unlisted UK shares (see note in Section 4.1). An asterisk indicates no de minimis exemption for financial assets.

Source: Authors' calculations based on the WAS, 2016-18.

\subsection{4 | De minimis exemptions}

The policy design of ACS includes exemptions for individual assets worth less than $£ 3,000$ (except in the case of financial assets, including shares). ${ }^{137}$ This cannot be modelled precisely with the WAS, as values are generally aggregated by asset type rather than reported on an asset-by-asset basis, although we expect that some asset types will reflect just one or two major assets (such as houses or business investments), while others will be the aggregated value of many smaller assets which are unlikely to be worth more than $£ 3,000$ each. We exempt all household contents from these calculations on the basis that these will typically reflect the value of multiple items which would not be aggregated, so even a reported total value that exceeds $£ 3,000$ would not imply that all the constituent assets would be chargeable assets under the wealth tax in most cases. Table 3 shows that the vast majority of individuals with property, pension and land wealth report the value of those assets to be well over $£ 3,000$. By contrast, physical assets are far less likely to be reported in large values.

In general, asset value figures in the remainder of section refer to chargeable wealth (i.e. wealth beyond the de minimis exempt level).

\footnotetext{
${ }^{137}$ In excluding low-value assets from our cost calculations, we are implicitly assuming that their having little or no marketable value can be established at no cost to the owner, which is not always realistic. It is conceivable, for example, that a business owner may need to pay a professional valuer to certify that the resale value of their business is well below the wealth tax threshold. We briefly touch on this issue as regards total wealth in Section 4.4.
} 
TA B L E 4 Assets by difficulty of valuation across the distribution

\begin{tabular}{|c|c|c|c|c|c|c|}
\hline \multirow[t]{2}{*}{ Range (£) } & \multicolumn{3}{|c|}{ Share of individuals (\%) who have: } & \multicolumn{3}{|c|}{ Share of total marketable value $(\%)$} \\
\hline & Easy assets & Mid assets & Hard assets & Easy assets & Mid assets & Hard assets \\
\hline $0-250 \mathrm{k}$ & 63.6 & 40.4 & 5.6 & 21.7 & 75.0 & 2.3 \\
\hline $250-500 \mathrm{k}$ & 96.6 & 99.3 & 18.6 & 19.1 & 78.5 & 2.2 \\
\hline $500 \mathrm{k}-1 \mathrm{~m}$ & 96.8 & 99.4 & 26.3 & 18.2 & 78.9 & 2.8 \\
\hline $1-2 \mathrm{~m}$ & 97.8 & 99.1 & 33.8 & 19.6 & 76.1 & 4.3 \\
\hline $2-5 \mathrm{~m}$ & 97.8 & 99.1 & 47.6 & 18.9 & 71.6 & 9.5 \\
\hline $5-10 \mathrm{~m}$ & 100.0 & 100.0 & 87.8 & 32.8 & 32.6 & 34.6 \\
\hline $10 \mathrm{~m}+$ & 100.0 & 98.1 & 96.0 & 15.0 & 17.1 & 67.9 \\
\hline
\end{tabular}

Note: Excludes assets falling below de minimis (most asset types $<£ 3,000$ ) and all household contents. Wealth thresholds and total wealth calculated with reference to total marketable wealth; columns 5-7 will not sum to 100 because of assets excluded by exemptions. The $£ 10 \mathrm{~m}+$ row should be interpreted with caution, as it is based on a relatively small number of WAS observations so may be subject to more uncertainty. Source: Authors' calculations based on the WAS, 2016-18.

TA B L E 5 Number of taxpayers needing professional valuations by threshold

\begin{tabular}{l|ll}
\hline Threshold $(\mathfrak{\xi})$ & Taxpayers (in thousands) with hard valuations & Share of taxpayer population $(\%)$ \\
\hline $250 \mathrm{k}$ & 3,884 & 25.0 \\
$500 \mathrm{k}$ & 2,522 & 30.6 \\
$1 \mathrm{~m}$ & 1,148 & 37.8 \\
$2 \mathrm{~m}$ & 335 & 53.1 \\
$5 \mathrm{~m}$ & 74 & 89.9 \\
$10 \mathrm{~m}$ & 21 & 96.0 \\
\hline
\end{tabular}

Note: To estimate counts of taxpayers, we add in individuals from the STRL, who have been excluded from earlier calculations. As we do not have information on the asset composition of these individuals, we estimate the share who would need professional valuations based on characteristics of WAS taxpayers with $£ 10 \mathrm{~m}+$ in wealth (as reported in Table 4).

Source: Authors' calculations based on the WAS, 2016-18, and STRL.

\subsection{Who would need professional valuations?}

Here, we explore how the incidence of each type of asset varies across different levels of wealth. Of most interest is the distribution of hard-to-value assets (i.e. business wealth, valuables, some unlisted shares, and land), as these will form the basis for the estimates of aggregate valuation costs. Across the distribution, there is a mix of asset types; however, for levels of wealth below $£ 5$ million, fewer individuals hold hard-to-value assets than those who do not (Table 4). ${ }^{138}$ Below $£ 5$ million in wealth, the vast majority of assets by value ( 90 per cent or more) are in the 'easy' or 'mid' categories.

As noted earlier, easy-to-value assets should not need professional valuations, and pensions and mid-difficulty assets are, by design, valued by pension funds and the VOA. Thus, the criterion for a taxpayer needing a professional valuation is possession of a hard-to-value asset. At a low tax threshold of $£ 500,000$, the absolute number of people needing a professional valuation is substantial (2.5 million of 8.3 million total taxpayers; see Table 5). ${ }^{139}$ At a higher threshold of $£ 2$ million, only an estimated

\footnotetext{
${ }^{138}$ As we rely on values as reported by owners for these hard-to-value assets (which under the policy design laid out by ACS would probably not be considered adequate for a self-assessment return), this remaining analysis should be considered quite approximate.

${ }^{139}$ In this section and the following, WAS data are augmented with information from the Sunday Times Rich List (STRL) to better capture wealth at the top of the distribution following the procedure outlined in Advani et al. (2021) (they are not included in the earlier analysis as there is no information on the asset composition). For the purposes of cost aggregates, a per-taxpayer valuation cost is calculated to apply to individuals listed in the STRL on the assumption that their portfolios are similarly hard to value as those at the top of the WAS wealth distribution (i.e. they are incurring costs at the maximum possible rate).
} 
TA B L E 6 Main assets of individuals who hold hard-to-value assets

\begin{tabular}{l|ll}
\hline Asset type & $\begin{array}{l}\text { Number of individuals with this } \\
\text { as main asset (in thousands) }\end{array}$ & $\begin{array}{l}\text { For whom, average } \\
\text { value (in thousands) }\end{array}$ \\
\hline Property excluding land & 2,932 & $£ 313$ \\
Benefit-style pensions & 1,632 & $£ 556$ \\
Business assets & 604 & $£ 971$ \\
Financial wealth & 455 & $£ 608$ \\
Land & 289 & $£ 283$ \\
Physical wealth & 184 & $£ 22$ \\
Contribution-style pensions & 76 & $£ 368$ \\
No single largest asset type & 260 & - \\
\hline
\end{tabular}

Note: Assumes no tax-free threshold. Benefit-style pension wealth includes the value of pensions in payment (this may include some DC pensions in payment, which are not separately identified in the WAS); contribution-style pension wealth includes DC and any other pension pots. Financial wealth includes listed and unlisted shares.

Source: Authors' calculations based on the WAS, 2016-18, and STRL.

335,000 taxpayers need professional valuations, but these make up a more substantial share of total taxpayers. For a threshold of $£ 10$ million, hard-to-value assets make up two-thirds of the value of assets and the vast majority of taxpayers have hard-to-value assets, but at that level the absolute number of taxpayers is small.

Who are the individuals likely to need professional assistance in making their valuations? And for which assets? By definition we might expect these to be mainly individuals whose main assets are business assets or land. However, even amongst the individuals who hold hard-to-value assets, these assets do not tend to dominate their wealth portfolio. More of these individuals report that their most valuable assets are property ${ }^{140}$ or pension wealth rather than more complex assets such as business assets (Table 6). That said, those individuals whose main assets are business assets report that these are much more valuable, on average, than the average values of other main asset types, but they make up less than 10 per cent of all individuals who have a hard-to-value asset.

\subsection{Costs to taxpayers by threshold}

Burgherr (2021) provides estimates of the cost of professional advisory services incurred by taxpayers under current tax regimes (in particular, ATED and IHT) that necessitate wealth valuation. These figures are informative for taxpayers who would be likely to need professional assistance to complete their returns, but as shown above we expect that a large share of taxpayers will not require such assistance. In this section, we combine Burgherr's estimates on the magnitude of valuation costs with the insights above from the WAS and Pentelow (2020) on which taxpayers are more likely to need professional assistance in complying with the wealth tax design as outlined in ACS. The results suggest that, given the strong assumptions outlined above and below, valuation costs to taxpayers could be contained to around 0.1 per cent or less of the total chargeable assets of the tax.

As noted earlier, we begin with the assumption that only hard-to-value assets (business wealth, private equity investment, collectables and land) incur a valuation cost substantial enough to be relevant for the purposes of this exercise; other asset types are valued by the VOA or pension funds (property and pensions), are small enough (household contents) to be likely exempt, or easy enough to

\footnotetext{
${ }^{140}$ Note the design in ACS includes houses being valued by the VOA, so property here (which excludes land assets) is not ultimately a valuation problem for the individuals. However, this does show that a substantial share of individuals would be affected if the VOA were not to take this responsibility.
} 
value (financial assets) that the vast majority of taxpaying households would not need a professional valuer's assistance.

This reduces the range of assets for which the taxpayer may need to pay a valuer's fee. Nonetheless, it is difficult to pin down what that fee might be. Burgherr (2021) provides evidence that the cost to taxpayers of valuations of property or business assets may vary by as much as a factor of 10 depending on the size, value and complexity of the asset. ${ }^{141}$ In addition, without any evidence on how these costs may vary across other types of assets (such as collectables), we are constrained to assuming they are not systematically more or less costly to value than property or business assets, despite the unique challenges faced in valuing each type of asset.

Figures quoted by Burgherr on professional valuations in the UK for ATED suggest an upper bound on costs of around 0.6 per cent of the value of the asset - this is the ratio of the highest of Burgherr's quoted fees $(£ 3,000)$ to the lowest ATED threshold $(£ 500,000)$. As we have emphasised, though, ATED valuations reflect the cost of valuing housing, which is likely to be easier to value than business assets. Costs for property valuation for IHT are similar, while there is a slightly higher upper bound of around 0.8 per cent for business valuation (the ratio of fees of $£ 2,500$ for a simple case ${ }^{142}$ to lowest threshold of $£ 325,000$ ).

Lower bounds on valuation costs are difficult to estimate, as much of the evidence presented by Burgherr suggests that valuation costs eventually reach an upper limit, while the wealth distribution has an extremely long tail. In general, we try to err towards assuming a more costly regime, although there are a number of reasons to believe these costs may already be on the high side: Burgherr's figures represent costs to taxpayers with very high wealth and/or complex affairs, and who interact (in the case of IHT) with a complex system of exemptions and reliefs, such that taxpayers may be willing to pay more in order for the prospect of reducing their tax bill. A wealth tax designed to avoid providing such incentives may carry lower valuation costs.

We proceed by assuming that the cost of a valuation is a fixed percentage of a taxpayer's hard-tovalue assets (business wealth, land, collectables and valuables, and some unlisted share holdings). This implicitly assumes both that the valuation of these assets can take place separately to the remaining assets making up a person's total wealth (or, equivalently, that adding these to the valuation does not add appreciably to its cost), and that the number of assets being valued does not influence cost. ${ }^{143}$ Based on the above work on current costs of valuation in the UK, we explore how costs vary between an upper bound rate ( 0.8 per cent of the asset's reported value, as per the estimated upper bound from Burgherr's IHT estimates), and an arbitrary low rate ( 0.1 per cent).

The effect of assuming that valuation costs are a fixed percentage of the value of complex assets is that the total valuation cost increases faster than wealth, as hard-to-value assets become a larger proportion of total wealth. While this seems reasonable at first, given the increasing complexity of wealthier individuals' portfolios, we cannot justify an assumption that leads valuation costs to increase more-than-proportionately with total wealth forever. This is supported by Burgherr's findings that valuation costs for ATED tend to cap out at around $£ 10,000$, and at around $£ 25,000$ (for business wealth only) for IHT. To reflect this, we cap total valuation costs at $£ 50,000$, a generous figure that

\footnotetext{
${ }^{141}$ Burgherr (2021) also notes that the costs quoted are not likely to be representative of the cost to an 'average' taxpayer, but rather to taxpayers with complex affairs - hence, we apply these costs to hard-to-value assets only. He also argues that the costs for a well-designed wealth tax with a broad base would likely lie between the costs for ATED and IHT.

${ }^{142}$ Burgherr notes that fees may be as high as $£ 25,000$, although this may reasonably be presumed to cover estates worth some order of magnitude more than $£ 325,000$.

${ }^{143}$ It would be preferable to calculate costs on a per-asset basis, as this approach does not make allowances for whether having multiple assets requiring valuation might increase costs, and we make some attempt at this in Section 4.4. However it is impossible to tell how many separate assets an individual possesses within the relevant asset types from the WAS data. In addition, our simple schedule for calculating valuation costs (as a fixed proportion of an asset's worth) means that aggregated valuation costs would only be affected by calculating costs on a per-asset (or per-asset-type) basis in the rare case of per-asset valuation costs exceeding $£ 50,000$.
} 
TA B L E 7 Administrative cost estimates under low and high valuation rates

\begin{tabular}{|c|c|c|c|c|c|}
\hline Threshold (£) & $\begin{array}{l}\text { Taxpayers } \\
\text { (in } \\
\text { thousands) }\end{array}$ & $\begin{array}{l}\text { Total } \\
\text { valuation cost } \\
\text { to taxpayers } \\
(£ \mathrm{~m}) \\
\end{array}$ & $\begin{array}{l}\text { Valuation } \\
\text { cost per } \\
\text { taxpayer (£) }\end{array}$ & $\begin{array}{l}\text { Valuation } \\
\text { cost as \% } \\
\text { chargeable } \\
\text { assets }\end{array}$ & $\begin{array}{l}\text { Valuation } \\
\text { cost as \% } \\
\text { taxable } \\
\text { assets }\end{array}$ \\
\hline \multicolumn{6}{|c|}{ Low valuation rate $(0.1 \%)$} \\
\hline $250 \mathrm{k}$ & 15,537 & 923 & 59 & 0.01 & 0.01 \\
\hline $500 \mathrm{k}$ & 8,240 & 866 & 105 & 0.01 & 0.01 \\
\hline $1 \mathrm{~m}$ & 3,035 & 762 & 251 & 0.01 & 0.02 \\
\hline $2 \mathrm{~m}$ & 631 & 624 & 990 & 0.02 & 0.03 \\
\hline $5 \mathrm{~m}$ & 83 & 483 & 5,845 & 0.03 & 0.04 \\
\hline $10 \mathrm{~m}$ & 22 & 342 & 15,699 & 0.03 & 0.04 \\
\hline \multicolumn{6}{|c|}{ High valuation rate $(0.8 \%)$} \\
\hline $250 \mathrm{k}$ & 15,537 & 5,288 & 340 & 0.04 & 0.06 \\
\hline $500 \mathrm{k}$ & 8,240 & 4,827 & 586 & 0.05 & 0.08 \\
\hline $1 \mathrm{~m}$ & 3,035 & 3,996 & 1,316 & 0.06 & 0.12 \\
\hline $2 \mathrm{~m}$ & 631 & 2,895 & 4,591 & 0.09 & 0.16 \\
\hline $5 \mathrm{~m}$ & 83 & 1,763 & 21,348 & 0.11 & 0.15 \\
\hline $10 \mathrm{~m}$ & 22 & 719 & 32,996 & 0.06 & 0.07 \\
\hline
\end{tabular}

Source: Authors' calculations based on the WAS, 2016-18, and STRL.

is intended to accommodate the larger number of assets which may need to be valued for wealthier individuals. $^{144}$

Aggregating valuation costs across all taxpayers, we can calculate average costs per taxpayer and total valuation costs as a share of assets captured by the tax (Table 7). This is a necessarily approximate exercise and is not expected to be particularly accurate on a taxpayer-by-taxpayer level, as valuation costs themselves will vary substantially across taxpayers. As an example, to the extent that some businesses are jointly owned, the cost of valuation of business assets will be overstated as the valuation on the whole business only needs to happen once.

Because of the way valuation costs are modelled, taxpayers' valuation costs depend on the threshold of the tax. Even so, these two broad scenarios suggest that aggregate costs to the taxpayer of valuing their wealth could be contained to less than 0.11 per cent ( 0.16 per cent) of total chargeable (taxable) wealth: $0.01-0.03$ per cent $(0.01-0.04$ per cent) in the low-rate scenario, and $0.04-0.11$ per cent $(0.06-$ 0.16 per cent) in the high-rate scenario.

Aggregate valuation costs decrease as the exemption threshold increases, as the number of taxpayers also falls; however, an increasing share of the remaining taxpayers hold hard-to-value assets, so average valuation costs increase. This is true also of valuation cost as a share of both chargeable assets (total assets of those captured by the tax) and taxable assets (i.e. excluding wealth below the tax threshold). The impact of the assumed $£ 50,000$ cap on professional fees is clearer in the high-cost scenario, with the relative cost of valuation falling between the $£ 5$ million and $£ 10$ million thresholds.

Costs in both scenarios are within or below Burgherr's estimate that the costs of administering a wealth tax for taxpayers are likely to be between 0.05 per cent and 0.3 per cent of taxable wealth, and well below the assumption of Troup et al. (2020) that taxpayer costs related to IHT range between 1

\footnotetext{
${ }^{144}$ It is possible that individual cases may exceed this figure, but on average there is scope for it to be offset by individuals who face a lower valuation cost. Nonetheless, Burgherr notes that the existence of the $£ 20 \mathrm{~m}+$ band for ATED significantly reduces the complexity of high-value property valuations; depending on the precise wealth tax design, the wealthy may have more need to establish a more precise point estimate of their wealth than under ATED.
} 
per cent and 1.5 per cent of total assets. ${ }^{145}$ The figures in Table 7 do not include other administrative costs, such as filing costs and costs of legal advice, so it is reasonable to expect that these estimates should be lower, and given that the wealth tax design examined is much less complex for the taxpayer than the current IHT regime, we think it is appropriate that our estimate is well below these latter figures.

Like wealth, valuation costs are highly positively skewed, and there is a great deal of heterogeneity. At a $£ 500,000$ wealth threshold, the average valuation cost amongst taxpayers with hard valuations (as opposed to amongst all taxpayers, as in Table 7) is $£ 325$ at the low valuation rate and $£ 1,900$ at the high rate; the median costs are $£ 20$ and $£ 160$, respectively. By comparison, the lowest valuation fee quoted by Burgherr (2021) is $£ 250$. Under either rate scenario, well under 1 per cent of taxpayers with valuation costs pay the (capped) $£ 50,000$. At a $£ 2 \mathrm{~m}$ threshold, the average cost is $£ 1,700$ at the low valuation rate and $£ 8,500$ at the high rate; the median costs are $£ 175$ and $£ 1,400$. Under the low rate, 0.2 per cent of taxpayers with hard-to-value assets pay the $£ 50,000$ maximum valuation charge, while over 6 per cent pay it under a high rate.

\section{4 | Sensitivity analysis}

As noted throughout this section, we have only limited information on costs, and a number of strong assumptions are needed to transform that information into total valuation cost estimates using data which, while very detailed, are not granular enough to allow for particularly sophisticated modelling. In this section, we explore how sensitive the above estimates are to alternative assumptions and approaches.

First, having a purely variable cost structure implies a cost for low-value items that is quite unrealistic; here, we explore how the cost estimates change if we assume a minimum fee is charged by valuers. Burgherr (2021) suggests that formal valuations for ATED and IHT start at $£ 1,500$ per property. Ideally, we would study how these costs would vary across numbers and types of assets, given the potential for costs to increase sharply if valuers have high per-asset minimum costs, but we have limited information on numbers of assets. It is also quite possible that minimum (or variable) components of cost vary across asset types; however, given the limited scope of ATED and IHT, we do not have any information to indicate whether, for example, an art collection would be consistently more costly to value than a family business. No doubt the introduction of a wealth tax would itself prompt changes in valuation cost structures by the extension of the need to value wealth to a different group of people, and a wider class of assets, than those currently subject to ATED and IHT. ${ }^{146}$

Table 8 shows how total valuation cost estimates change with two types of minimum cost: one at $£ 1,500$ per taxpayer needing a valuation, and the second at $£ 1,500$ per asset category (business wealth, unlisted shares, land wealth, and collectables and valuables), implying a minimum cost of up to $£ 6,000$ (although the valuation cost may be lower for individuals with wealth in fewer asset categories). The results show there is substantial scope for aggregate costs to increase at lower thresholds; however, at higher thresholds, most taxpayers' valuation costs are already above the applied minimum fees, so there is little difference in the aggregate cost. Moreover, it is not the overall cap in cost at $£ 50,000$ which constrains cost estimates at the higher end; applying this cap too on a per-asset-category basis does not appreciably increase valuation costs (i.e. the cap does not bite for most taxpayers). Costs in these scenarios range from 0.03 per cent to 0.13 per cent of chargeable assets.

\footnotetext{
145 As Burgherr (2021) notes, there are good reasons to expect that 1-1.5 per cent may overstate the likely costs for the majority of taxpayers; much of the probate process, which contributes to IHT costs, would not be necessary in the case of a wealth tax, and estimates representing the fees of top firms will not be representative of costs for many taxpayers with less complicated affairs.

${ }^{146}$ As noted, we do not have information on the composition of assets of individuals listed in the STRL so we cannot apply per-category minimum costs; we assume the maximum cap at $£ 50,000$ applies to all these individuals (and a $£ 200,000$ cap in the per-asset maximum scenario).
} 
TA B L E 8 Additional valuation costs with minimum fees

\begin{tabular}{|c|c|c|c|c|c|c|}
\hline \multirow[t]{2}{*}{ Threshold (£) } & \multicolumn{2}{|c|}{ Total valuation cost } & \multicolumn{2}{|c|}{ Total valuation cost } & \multicolumn{2}{|c|}{ Total valuation cost } \\
\hline & $\begin{array}{l}\ldots \text { with } \\
£ 1,500 \\
\text { minimum } \\
(£ m)\end{array}$ & $\begin{array}{l}\text {...as } \% \\
\text { chargeable } \\
\text { assets }\end{array}$ & $\begin{array}{l}\text {...with } £ 1,500 \\
\text { minimum per } \\
\text { asset category } \\
(£ m)\end{array}$ & $\begin{array}{l}\text {...as } \% \\
\text { chargeable } \\
\text { assets }\end{array}$ & $\begin{array}{l}\ldots \text { with } £ 1,500 \\
\text { min and } £ 50 \mathrm{k} \\
\text { max per asset } \\
\text { category }(£ m)\end{array}$ & $\begin{array}{l}\text {...as } \% \\
\text { chargeable } \\
\text { assets }\end{array}$ \\
\hline \multicolumn{7}{|c|}{ Low valuation rate $(0.1 \%)$} \\
\hline $250 \mathrm{k}$ & 6,254 & 0.05 & 7,052 & 0.06 & 7,210 & 0.06 \\
\hline $500 \mathrm{k}$ & 4,214 & 0.04 & 4,798 & 0.05 & 4,956 & 0.05 \\
\hline $1 \mathrm{~m}$ & 2,156 & 0.03 & 2,528 & 0.04 & 2,686 & 0.04 \\
\hline $2 \mathrm{~m}$ & 938 & 0.03 & 1,091 & 0.04 & 1,249 & 0.04 \\
\hline $5 \mathrm{~m}$ & 519 & 0.03 & 579 & 0.04 & 737 & 0.05 \\
\hline $10 \mathrm{~m}$ & 351 & 0.03 & 367 & 0.03 & 525 & 0.04 \\
\hline \multicolumn{7}{|c|}{ High valuation rate $(0.8 \%)$} \\
\hline $250 \mathrm{k}$ & 9,432 & 0.08 & 10,122 & 0.08 & 10,351 & 0.08 \\
\hline $500 \mathrm{k}$ & 7,338 & 0.07 & 7,818 & 0.08 & 8,048 & 0.08 \\
\hline $1 \mathrm{~m}$ & 4,955 & 0.08 & 5,242 & 0.08 & 5,471 & 0.09 \\
\hline $2 \mathrm{~m}$ & 3,090 & 0.10 & 3,193 & 0.10 & 3,422 & 0.11 \\
\hline $5 \mathrm{~m}$ & 1,784 & 0.11 & 1,813 & 0.11 & 2,042 & 0.13 \\
\hline $10 \mathrm{~m}$ & 724 & 0.06 & 725 & 0.06 & 936 & 0.08 \\
\hline
\end{tabular}

Note: Total chargeable assets and number of taxpayers, as in Table 7.

Source: Authors' calculations based on the WAS, 2016-18, and STRL.

It is overly simplistic to assume that valuation costs are only incurred by taxpayers captured by the tax. Uncertainty about their precise wealth may incentivise individuals with total wealth below the tax threshold to have their assets valued by a professional valuer, even if the final outcome is that they are, in fact, not liable for the tax. Even so, this is not likely to add significantly to aggregated valuation costs. Table 9 shows that individuals with wealth up to 10 per cent below the threshold are (by definition) less wealthy and (more crucially) hold less of their wealth in hard-to-value assets than the average taxpayer. Allowing for the valuation costs of these individuals increases the aggregate cost

TA B L E 9 Additional valuation costs to individuals below the threshold

\begin{tabular}{|c|c|c|c|c|c|c|c|}
\hline \multirow[t]{2}{*}{ Threshold (£) } & \multirow{2}{*}{$\begin{array}{l}\text { Individuals } \\
\text { with wealth } \\
\text { up to } 10 \% \\
\text { below } \\
\text { threshold } \\
\text { (in } \\
\text { thousands) }\end{array}$} & \multicolumn{2}{|c|}{$\begin{array}{c}\text { Total additional } \\
\text { valuation cost }(\%)\end{array}$} & \multicolumn{2}{|c|}{$\begin{array}{l}\text { Average chargeable wealth } \\
\qquad(£ \mathrm{~m})\end{array}$} & \multicolumn{2}{|c|}{$\begin{array}{c}\text { Share of total chargeable } \\
\text { wealth that is hard to value } \\
(\%)\end{array}$} \\
\hline & & $\begin{array}{l}\text { Low } \\
\text { valuation } \\
\text { rate } \\
(0.1 \%)\end{array}$ & $\begin{array}{l}\text { High } \\
\text { valuation } \\
\text { rate } \\
(0.8 \%)\end{array}$ & $\begin{array}{l}\text { Individuals } \\
\text { below } \\
\text { threshold }\end{array}$ & Taxpayers & $\begin{array}{l}\text { Individuals } \\
\text { below } \\
\text { threshold }\end{array}$ & Taxpayers \\
\hline $250 \mathrm{k}$ & 1,114 & 0.7 & 1.0 & 0.24 & 0.81 & 2.5 & 6.9 \\
\hline $500 \mathrm{k}$ & 995 & 1.3 & 1.8 & 0.48 & 1.21 & 2.3 & 8.2 \\
\hline $1 \mathrm{~m}$ & 638 & 2.8 & 4.2 & 0.95 & 2.08 & 3.5 & 11.3 \\
\hline $2 \mathrm{~m}$ & 208 & 2.7 & 4.6 & 1.9 & 4.9 & 4.2 & 18.6 \\
\hline $5 \mathrm{~m}$ & 17 & 1.9 & 4.3 & 4.7 & 19.3 & 11.9 & 27.2 \\
\hline $10 \mathrm{~m}$ & 4 & 1.4 & 5.5 & 9.3 & 54.5 & 13.7 & 24.6 \\
\hline
\end{tabular}

Note: Additional valuation cost calculated with reference to cost in Table 7.

Source: Authors' calculations based on the WAS, 2016-18, and STRL. 
estimate by only 1-6 per cent, and has a negligible effect on the ratio of valuation costs to chargeable assets (not shown).

\section{5 | CONCLUSION}

Open market valuation is the preferred aim of valuation for a net wealth tax. It is the primary concept used in many current/former wealth taxes and existing UK taxes, as well as in non-tax situations, and finds general support in the tax policy literature. In many cases, open market valuations will be relatively easy to determine by reference to market transactions, and technological innovation has assisted in that regard in recent years. However, open market valuation can be problematic to determine for certain assets. Most dramatically, this difficulty may be one explanation (amongst others) for the outright exemption from, or preferential treatment under, existing and former wealth taxes for pensions, primary residences, business assets, agricultural property and art/antiques. However, such exemptions raise horizontal equity and neutrality concerns and are difficult to justify on tax policy grounds. Moreover, in our view, options are available for arriving at an open market value even for the most problematic assets. This includes using CE figures for DB pensions, current mid auction estimates for artwork, and valuing many small private businesses without taking into account value attributed to the human capital of the business owners.

Simpler valuation methods may be preferable to an open market valuation approach in some cases, however. For example, a book value method, as used in Switzerland, could be applied to value private companies and some form of insurance value used for valuable chattels such as antiques. In addition, an argument can be made for less frequent valuation for especially problematic assets. Like exemptions, however, measures such as these aimed at certainty and feasibility come at the substantial expense of consistency and integrity, and ultimately we recommend against adopting these approaches.

Finally, it is worth noting that the scale and prevalence of such problems may depend quite significantly on the exemption threshold of the tax; at higher thresholds, the taxpayers captured are far less numerous but tend to have more complex affairs. Our estimates of the costs to taxpayers affected by the difficulty of obtaining a precise valuation of particular assets (in this case, predominantly business assets, land and collectables) suggest that, in aggregate, costs could be contained to around 0.1 per cent or less of total chargeable assets, even if they are substantial for some individual taxpayers. However, we caution that these estimates are based on limited information on valuation costs applying to taxes which only a small number of parties face, and that that information may bear little resemblance to the wholesale changes in valuers' cost structures that the introduction of a wealth tax could prompt. Under the design of ACS, there would nonetheless be additional valuation costs incurred by the government and government agencies, as well as pension providers, in addition to costs related to administration and compliance.

\section{ACK N OW L ED G EMENTS}

The authors thank Clive Beer and Wojciech Kopczuk for helpful comments on an earlier draft, the three anonymous reviewers for Fiscal Studies, Andy Lymer for his early work on the project, the authors of the Wealth Tax Commission background papers on valuation for their contributions (David Burgherr, Elizabeth Clark, Christopher Eames, Shaun Fu, Ian Mackie, Jenny Nelder, Antonia Ramm, Daniel Ryan, Lindsay Pentelow and Anastasia Tennant), and Elizabeth Clark and Antonia Ramm for their excellent research assistance.

A previous version of this work circulated as Wealth Tax Commission Evidence Paper No. 9. The Wealth Tax Commission acknowledges funding from the Economic and Social Research Council (ESRC) through CAGE at Warwick (ES/L011719/1) and a COVID-19 Rapid Response Grant (ES/V012657/1), and from the LSE International Inequalities Institute AFSEE COVID-19 fund. 


\section{R E F E R E N C ES}

Advani, A., Chamberlain, E. \& Summers, A. (2020), A wealth tax for the UK: final report. Wealth Tax Commission, https: //doi.org/10.47445/114

Advani, A., Hughson, H. M. \& Tarrant, H. M. (2021), Revenue and distributional modelling for a UK wealth tax. Fiscal Studies, $42,699-736$.

Advani, A. \& Tarrant, H.M. (2021), Behavioural responses to a wealth tax. Fiscal Studies, 42, 509-38.

Atkinson, A. B. (1972), Unequal Shares: Wealth in Britain. London: Penguin Press.

Banoun, B. (2020), Norway. Wealth Tax Commission Background Paper No. 138.

Boadway, R., Chamberlain, E. \& Emmerson, C. (2010), Taxation of wealth and wealth transfers. In S. Adam et al., Dimensions of Tax Design: The Mirrlees Review. Oxford: Oxford University Press.

Burgherr, D. (2021), The costs of administering a wealth tax. Fiscal Studies, 42, 677-98.

Chamberlain, E. (2021), Who should pay a wealth tax? Some design issues. Fiscal Studies, 42, 599-614.

Clark, E. \& Fu, S. (2020), Valuation of agricultural property. Wealth Tax Commission Working Paper No. 145.

Cribb, J., Miller, H. \& Pope, T. (2019), Who are business owners and what are they doing? Institute for Fiscal Studies (IFS) Report No. 158, https://doi.org/10.1920/re.ifs.2019.0158.

Daly, S. (2020), Tax Authority Advice and the Public. Oxford: Hart Publishing.

Devereux, M. P. \& Vella, J. (2018), Gaming destination based cash flow taxes. Tax Law Review, 71, 477-514.

Dupas, M. (2020), Wealth taxes in France (1). Wealth Tax Commission Working Paper No. 134.

Eckert, J.-B. \& Aebi, L. (2020), Wealth taxation in Switzerland. Wealth Tax Commission Working Paper No. 133.

Evans, C. et al. (2017), Comparative Taxation: Why Tax Systems Differ. Cheltenham: Fiscal Publications.

HMRC (2016), Shares and Assets Valuation Manual: SVM113130 - The Statutory Open Market: Case Law Valuation decisions reached in particular cases. Available at https://www.gov.uk/hmrc-internal-manuals/shares-and-assetsvaluation-manual/svm113130.

HMSO (1974), Wealth Tax, Green paper, Cmnd 5704. London: HMSO.

Hughson, H. M. (2020), Banding. Wealth Tax Commission Working Paper No. 147.

International Valuation Standards Council (2019), International Valuation Standards: Effective 31 January 2020. London: International Valuation Standards Council.

International Valuation Standards Council (2016), International Valuation Standards 104: Bases of Value. London: International Valuation Standards Council.

Loutzenhiser, G. \& Mann, E. (2021), Liquidity issues: solutions for the asset rich, cash poor. Fiscal Studies, 42, 651-76.

Mackie, I. (2020), Valuation of commercial and residential real estate assets. Wealth Tax Commission Working Paper No. 143.

McDonnell, T. A. (2013), Wealth tax: options for its implementation in the Republic of Ireland. NERI Working Paper Series, WP 2013/6.

Meade, J. (Chair of Committee) (1978), The Structure and Reform of Direct Taxation. London: Institute for Fiscal Studies.

Mirrlees, J. et al. (2011), Tax by Design: The Mirrlees Review. Oxford: Oxford University Press.

Nelder, J. (2020), Valuation of unincorporated businesses (sole traders and partnerships) and shareholdings in private companies. Wealth Tax Commission Working Paper No. 141.

OECD (2018), The Role and Design of Net Wealth Taxes in the OECD, OECD Tax Policy Studies, Vol. 26. Paris: OECD Publishing, https://doi.org/10.1787/9789264290303-en.

ONS, Social Survey Division (2020), Wealth and Assets Survey, Waves 1-5 and Rounds 5-6, 2006-18. [data collection]. 13th Edition. UK Data Service SN: 7215.

Peacock, A. (1963), Economics of net wealth tax for Britain. British Tax Review, 1963(6), 388-99.

Pensions Advisory Group (2019), A Guide to the Treatment of Pensions on Divorce.

Pentelow, L. (2020), UK tax valuation and potential wealth tax. Wealth Tax Commission Working Paper No. 146.

Ramallo, A. (2020), Wealth tax: Spain. Wealth Tax Commission Working Paper No. 132.

Ramm, A. and Eames C. (2020), Valuation of pensions. Wealth Tax Commission Working Paper No. 142.

Rehr, R. (2020), Wealth tax: Germany. Wealth Tax Commission Working Paper No. 131.

Repetti, J. (2000), It's all about valuation. Tax Law Review, 53, 607-14.

Ryan, D. (2020), Valuation of businesses and intellectual property assets. Wealth Tax Commission Working Paper No. 144.

Saez, E. \& Zucman, G. (2019a), Progressive wealth taxation. Brookings Papers on Economic Activity, (Fall), $437-533$.

Saez, E. \& Zucman, G. (2019b), The Triumph of Injustice: How the Rich Dodge Taxes and How to Make Them Pay. New York: W. W. Norton.

Sandford, C. \& Morrissey, O. (1985), The Irish Wealth Tax: a case study in economics and politics. The Economic and Social Research Institute, Paper No. 123.

Sandford, C., Willis, J. \& Ironside, D. (1975), An Annual Wealth Tax. London: Heinemann Educational Publishers.

Tennant, A. (2020), The valuation of chattels. Wealth Tax Commission Working Paper No. 140.

Thuryoni, V. (2003), Comparative Tax Law. The Hague: Kluwer Law International. 
Tirard, J.-M. (2020), Wealth taxes in France (2). Wealth Tax Commission Working Paper No. 135.

Troup, E., Barnett, J. \& Bullock, K. (2020), The administration of a wealth tax. Wealth Tax Commission Evidence Paper No. 11.

Vanvari, G. \& TA, K. (2020), Wealth tax: India. Wealth Tax Commission Working Paper No. 137.

How to cite this article: Daly S., Hughson H. \& Loutzenhiser G. (2021), Valuation for the purposes of a wealth tax. Fiscal Studies, 42:615-650.

https://doi.org/10.1111/1475-5890.12287 